\title{
An annotated type catalogue of the frogs (Amphibia: Anura: Limnodynastidae, Myobatrachidae, Pelodryadidae) in the collection of the Western Australian Museum
}

\author{
Ryan J. Ellis ${ }^{1 *}$, Paul Doughty ${ }^{1}$ and J. Dale Roberts ${ }^{2}$ \\ 1 Department of Terrestrial Zoology, Western Australian Museum, 49 Kew Street, Welshpool, \\ Western Australia 6106, Australia. \\ ${ }^{2}$ Centre of Excellence in Natural Resource Management, University of Western Australia, \\ PO Box 5771, Albany, Western Australia 6332, Australia. \\ * Corresponding author: ryan.ellis@museum.wa.gov.au
}

\begin{abstract}
An annotated catalogue is provided for all primary and secondary type specimens of frogs (Amphibia: Anura) currently and previously held in the herpetological collection of the Western Australian Museum (WAM). The collection includes a total of 613 type specimens (excluding specimens maintained as possible paratypes) representing 55 species or subspecies of which four are currently considered junior synonyms of other species. The collection includes 44 holotypes, 3 lectotypes, 36 syntypes, 462 paratypes and 68 paralectotypes. In addition, the collection includes 392 specimens considered possible paratypes where paratype specimens could not be confirmed against specimens held in the WAM for five species (Heleioporus barycragus, H. inornatus, H. psammophilus, Crinia pseudinsignifera and $C$. subinsignifera). There are 23 type specimens and seven possible paratypes that have not been located, some of which were part of historic disposal of specimens, and others with no records of disposal, loan or gifting and are therefore considered lost. Type specimens supposedly deposited in the WAM by Harrison of the Macleay Museum, University of Sydney, for Crinia rosea and Pseudophryne nichollsi were not located during the audit of types and are considered lost.
\end{abstract}

KEYWORDS: type specimens, holotype, lectotype, syntype, paratype, paralectotype, allotype, frog

\section{INTRODUCTION}

Since the establishment of the Western Australian Museum (WAM) in 1891, its natural history collection has grown substantially to become one of the largest collections in Australia, and one of the largest regional collections in the world. Amphibian specimens make up about 29,000 of the 160,000 specimens in the herpetological collection. Initially herpetofauna specimens were accessioned into a series of six general hardcopy catalogues from 1891 to 1912. The registers were used to document all material obtained by the museum, including material for terrestrial and aquatic zoology, history, anthropology and archaeology collections. The earliest anuran acquisition by the WAM listed in the WAM donations register 1896-1900, dated 20 July 1896 was part of a group of specimens. The entry states ' 2 bottles containing...2 frogs, 1 snake, 15 lizards, 26 (insects and crabs)' from 'Broome'; however, no further information is provided. The acquisition was also published in the local press on 10 August 1986
(Anonymous 1986), where many early donations and purchases of the WAM were published prior to the use of formal registers. The article lists the acquisition as a museum purchase, stating 'three bottles containing two frogs, one snake, 15 lizards, 26 insects and crabs, etc' (Anonymous 1896). The species identification of the two frog specimens or their whereabouts is unknown as no registration number, additional specimen information or species identification are provided in the register or local press article.

In 1912 a hardcopy catalogue was established specifically for herpetological specimens. Specimens accessioned into the herpetological catalogue obtained a registration number prefixed with ' $R$ ' for 'reptiles', although this collection also includes amphibians. This prefix is still in use to denote registration numbers and specimens in the herpetological collection. Where associated specimens and information could be identified for pre-departmental registration numbers, the specimens were re-catalogued into the new cataloguing 
system and given ' $\mathrm{R}$ ' numbers. It is not known if this was completed for the entire collection; however, after review of historic catalogues, an attempt to re-catalogue specimens accessed prior to the current herpetology catalogue (pre-1912) was completed in stages by numerous museum staff. Many historic specimens have notations indicating a specimen has been re-catalogued in the new system and the date when this was done, sometimes signed by the person responsible. A large number of catalogue entries are not accompanied with notations of re-cataloguing and there is no information about specimens gifted to other institutions, discarded or lost. The earliest anuran specimen documented in the WAM herpetofauna catalogue is a Myobatrachus gouldii (turtle frog), R39, accessioned 30 August 1912. All specimens formerly registered in the hardcopy catalogues given registrations bearing the ' $R$ ' prefix have since been entered into the current electronic database of herpetological specimens. Any new specimens registered into the herpetological collection are now entered into the electronic herpetological database.

The collection is primarily composed of Western Australian species, but does contain comparative material from other Australian states and some international locations, including Malaysia (36 species), Indonesia (10), and New Guinea (10), and species from other countries including Canada, India, Nicaragua, Philippines, Solomon Islands, U.K., U.S.A. and various countries in Africa. Anurans are represented by a total of 29,014 registered specimens (as of 28 December 2016), with approximately 2,100 lots of unregistered tadpoles and eggs. Adults and juveniles have been fixed in a $10 \%$ formalin solution and are stored in a $70 \%$ ethanol solution and tadpoles in 5\% formalin solution. There are also select alizarin-alcian stained and skeletal preparations of adults for some species. Over 7500 type specimens are held in the reptile and amphibian collection with 613 specimens representing types of 55 anuran species or subspecies: 83 primary types (44 holotypes, 3 lectotypes and 36 syntypes) and 530 secondary types (462 paratypes and 68 paralectotypes). A further 392 specimens are regarded as possible paratypes for species or subspecies where original descriptions clearly used other specimens, in addition to the type, which often attributed to description of variation or are listed as a specimen examined; however, insufficient detail is provided to confirm the identity of these paratypes. Potential paratypes listed here are specimens that were probably included in the description of the species based on the often limited information provided by authors; however, they cannot be confirmed. We recognise possible paratypes for five species: Heleioporus barycragus, H. inornatus, H. psammophilus, Crinia pseudinsignifera and C. subinsignifera. In some cases, the number of possible paratypes exceeds the number of specimens listed in the original description while in others there are fewer which suggests the number of confirmed type specimens and the number of specimens considered lost may be greater or less than previously indicated. Historic disposal of specimens at the WAM has occasionally occurred with the reason for most not well documented; however, in the past, disposals have often been attributed to poor condition of specimens. In some circumstances, the taxonomic status of a species was believed to be resolved and additional specimens or those in poor condition were considered not necessary to retain in the collection. The disposal of specimens following registration into the WAM herpetological collection has previously been noted (Smith 1981). The WAM type collection currently holds type material for 49 of the 85 currently recognised native anuran species known to occur in WA. Of the 64 anuran species or subspecies described from Western Australian localities, type material for $45(70 \%)$ are currently housed in the WAM collection. The remaining 19 species described from WA localities not represented in the WAM anuran type collection include two Pelodryadidae (Litoria adelaidensis and Litoria cyclorhyncha), six Limnodynastidae (Heleioporus albopunctatus, Heleioporus eyrei, Limnodynastes dorsalis, Neobatrachus wilsmorei, Neobatracthus pelobatoides, Notaden nichollsi) and 11 Myobatrachidae (Myobatrachus gouldii, Crinia georgiana, Crinia glauerti, Crinia insignifera, Geocrinia leai, Geocrinia rosea, Pseudophryne guentheri, Pseudophryne nichollsi, Pseudophryne occidentalis, Uperoleia marmorata and Uperoleia mjobergii).

Until the early 2000s, the taxonomic interests of WAM herpetology curators was almost exclusively focussed on Western Australian reptiles. In contrast, most of the early taxonomic work on Western Australian frogs was carried out by researchers based in the U.K. or U.S.A. until about the mid-20th century. Many of the described species during this early period have widespread distributions, with types taken from eastern or northern states and territories, but with ranges extending into Western Australia. The result is that there are few types of such widespread species in the WAM from these early descriptions. Beginning in the 1950s and continuing to the present day, frog biologists based at the University of Western Australia (UWA) such as Albert 'Bert' Russell Main, Murray John Littlejohn and John 'Dale' Roberts focussed on aspects of evolution and ecology of frogs (see Shea 2014), with taxonomic outputs as a result of their findings, especially with species endemic to arid and south-western WA. In contrast, researchers from South Australia, usually led by Michael 'Mike' John Tyler and Margaret Davies from the University of Adelaide and the South Australian Museum, along with 
Angus Anderson Martin and Graeme Field Watson (University of Melbourne), carried out extensive early fieldwork in the Kimberley region in the 1970s and 1980s with a focus on taxonomy. Collecting permits issued for fieldwork in Western Australia require holotypes and a portion of the paratypes collected to be deposited at the WAM, resulting in many of the South Australian group's Kimberley types being deposited here. Collection of specimens from the Kimberley was also supported by the collecting efforts of Lawrence 'Laurie' Alex Smith and Ronald 'Ron' Eric Johnstone as part of WAM's Kimberley expeditions in the 1970s and 1980s. More recently, Doughty and colleagues have added Kimberley and arid zone type specimens as part of an active research programme on frog systematics (e.g. Doughty and Anstis 2007; Doughty and Roberts 2008; Doughty et al. 2009; Anstis et al. 2010; Catullo et al. 2011; Doughty 2011; Catullo et al. 2014; Anstis et al. 2016).

The WAM published a list of types annually in the WAM Annual Report from 1960 to 1969, discontinued in 1970 (Anonymous 1970). A total of 10 parts of the type list were presented, of which only parts 2 (196061), 4 (1962-63), 5 (1963-64), 6 (1964-65), 8 (1966-67) and 10 (1968-69) included anuran material (Anonymous 1961, 1963, 1964, 1965, 1967, 1969). The Annual Report type lists present primary types for 12 anuran type specimens in the herpetological lists, compiled by Glen Milton Storr. Primarily holotypes and lectotypes, and occasionally syntypes and neotypes, were listed, with no secondary types listed. Since the 1970 Annual Report, no further type lists or catalogues have been published for the type material held in the herpetological collection of the WAM. In accordance with Recommendation $72 \mathrm{~F}$ of the International Code of Zoological Nomenclature (ICZN 1999), a type specimen audit was commenced in order to publish a current type catalogue of the material held in the WAM herpetological collection. Due to the size of the herpetological type collection, a decision to publish separate type catalogues by taxonomic group was made. The first of a series of publications presenting the type material held in the herpetological collection of the WAM, a type catalogue of the turtles (Chelidae) was published in mid-2015 (Ellis and Georges 2015). The present type catalogue is the second of this series.

\section{METHODS}

Information on type specimens was obtained from the original description and compared with information retrieved from accession data on the museum database, jar labels, personal communications and subsequent publications relating to relevant type material. All type specimens in the collection of the WAM were examined in addition to label information and notations. Extensive searches of the collection, accession data, original descriptions and other records were undertaken during the audit to locate missing specimens or those lacking data. This catalogue also includes type specimens of species that have, since their description, been synonymised and/or resurrected from synonymy with other taxa. This catalogue was prepared in accordance with the rules, recommendations, definitions and amendments of the International Code for Zoological Nomenclature (ICZN 1999, 2003, 2012).

As higher level frog taxonomy is in a state of flux owing to new molecular genetic phylogenies, we follow the Australian Society of Herpetologists (ASH) Species List of Australian Amphibians and Reptiles as of 20 December 2016 (http://www. australiansocietyofherpetologists.org/positionstatements/, position statement \#3). This list maintains usage of the genus Cyclorana Steindachner (contra Frost et al. 2006; Duellman et al. 2016; Dubois and Frétey 2016) and also does not recognise Ranoidea Tschudi (Dubois and Frétey 2016; formerly the Dryosophus Fitzinger resurrected by Duellman et al. 2016) for approximately half the species of Litoria.

\section{FORMAT}

This catalogue follows the format of a previous WAM type catalogue by Ellis and Georges (2015).

\section{ORIGINAL BINOMEN}

\section{Genus species subspecies Author, year}

\section{Original type species citation}

Author, year, title, journal, page(s), [page of description].

\section{Primary type (holotype/lectotype/syntypes)}

Registration number, locality (latitude/longitude), collector(s) and collection date.

\section{Secondary type(s) (paratype/paralectotype/allotype/} possible paratypes) (number of types in WAM collection)

Registration number, locality.

\section{Current nomenclature}

Current generic and specific recognition of the species.

\section{Current status}

Current status and validity of the species, synonymies.

\section{Remarks}

Additional information provided on subjects including the history and status of types, location of additional type specimens and information regarding the synonymy or resurrection of a species or subspecies if necessary and available. 
Each taxon is presented by the name provided by the original author(s), followed by the author's name, and year of publication. Species names are given in the exact format in which they were first published. The original type species publication citation follows next displaying the author(s), year, title (of article or book), journal (unless otherwise), page(s) and the page on which the species description commences in square brackets. Primary type (holotype, lectotype or syntype/s) information includes WAM registration number, locality, latitude and longitude (in degrees minutes seconds, where recorded to that precision), collector(s) name and collection date. Primary type localities and coordinates shown in quotes are those presented in the original published descriptions. Coordinates presented in square brackets that lack quotes are those that have been identified from accession data not presented in the original description or subsequently determined based on locality data presented in the description. All dates are presented as day - month - year, month - year, or year, as presented in the original description or relevant information sources. Secondary types (paratype/s, paralectotype/s and possible paratypes) are displayed showing WAM registration number and locality. Specific locality (latitude and longitude) and collection details (collector and date) are not provided for secondary type specimens. Possible paratypes are listed where it is clear additional specimens were included in the original description; however, no registration number was provided and only limited information was available. Where specimens that were likely to have been included matched data provided in the description but could not be confirmed, the species are recognised as possible paratypes. Specimens marked with an asterisk (*) are no longer held in the collection of the WAM, either due to gifting to another institution, disposal by WAM or loss of specimen. Details of specimens no longer held in the collection are discussed further in the Remarks section of each species where information was available. Current nomenclature and status are only presented where change from the original binomen has occurred, such as generic changes, specific amendments, changes to species or subspecies status and synonymy or resurrection from synonymy.

Remarks include relevant information on issues and errors from original descriptions, specimens, historical remarks or subsequent publications referring to the species or specimens as well as information relating to the synonymy or resurrection of the species or information pertaining to lost or destroyed specimens. Where call recordings from type material were used as part of the species description, the format, location and status of the recordings is presented where known. Where known, tissue samples for holotypes are presented with tissue type, storage method and storage location. Secondary type material with tissue samples deposited in the WAM are presented with tissue type and storage method where known. Tissue samples for type material that has been depleted is not presented. Square brackets indicate corrections or additions to information presented in the original description or subsequent publications. The prefix $\mathrm{R}$ is used to indicate that the registration number corresponds with the herpetofauna collection of the WAM.

Institution abbreviations follow Sabaj Pérez (2014) with the addition of the Arid Zone Research Institute, Alice Springs, Northern Territory, Australia (AZRI), Centre of Excellence in Natural Resource Management, University of Western Australia, Albany, WA (CENRM) and University of Western Australia, Crawley, WA, Australia (UWA). We have used the following abbreviations in presenting type information in this catalogue.

AMNH American Museum of Natural History, New York, U.S.A.

AMS Australian Museum, Sydney, New South Wales, Australia

AZRI Arid Zone Research Institute, Alice Springs, NT, Australia (transferred into the NTM in 1985, see Horner 1999).

BMNH Natural History Museum (formerly British Museum (Natural History)), London, England, U.K.

CAM Central Australian Museum Alice Springs, NT, Australia (transferred into the NTM in 1985, see Horner 1999). Also referred to as Central Australian Wildlife Collection (CAWC).

CENRM Centre of Excellence in Natural Resource Management, University of Western Australia, Albany, WA

the Code the International Code of Zoological Nomenclature

E east

EBU Evolutionary Biology Unit, South Australian Museum, Adelaide, SA, Australia

ENE east-northeast

ESE east-southeast

HS Homestead

Hwy Highway

ICZN International Commission for Zoological Nomenclature

Is Island

km kilometres 
$\begin{array}{ll}\text { KU } & \text { University of Kansas Natural History } \\ & \text { Museum, Lawrence, Kansas, U.S.A. } \\ \text { MCZ } & \text { Museum of Comparative Zoology, Harvard } \\ & \text { University, Cambridge, Massachusetts, } \\ & \text { U.S.A. } \\ \text { mi } & \text { miles }\end{array}$

MMUS Macleay Museum, University of Sydney, New South Wales, Australia

Mt Mount

$\mathrm{N} \quad$ north

NE northeast

NMV Museum Victoria (formerly National Museum of Victoria), Melbourne, Victoria, Australia

NNW north-northwest

NP national park

NR nature reserve

$\mathrm{nr} \quad$ near

NT Northern Territory, Australia

NTM Museums and Art Galleries of the Northern Territory (formerly Northern Territory Museum of Arts and Sciences), Darwin, NT, Australia

NW northwest

Qld Queensland, Australia

QM Queensland Museum, Brisbane, Qld, Australia

QVM Queen Victoria Museum and Art Gallery, Launceston, Tasmania, Australia

Rd Road

S south

SA South Australia, Australia

SAMA South Australian Museum, Adelaide, SA, Australia

SE $\quad$ southeast

SUM Stellenbosch University, John R. Ellerman Museum of Zoology, Cape Town, South Africa

SSE South-southeast

SSW south-southwest

Stn Station

SW southwest

UWA University of Western Australia, Crawley, WA, Australia

W west

WA Western Australia

WAM Western Australian Museum, Perth, WA, Australia

\section{ACCOUNT OFTYPE SPECIMENS}

\section{ANURA}

\section{Family Limnodynastidae}

Heleioporus barycragus Lee, 1967

Lee, A.K. (1967) Studies in Australian Amphibia II. Taxonomy, ecology, and evolution of the genus Heleioporus Gray (Anura: Leptodactylidae). Australian Journal of Zoology 15: 367-439 [390].

\section{Holotype}

R21869 (formerly UWA Zoology Department collection, A.R. Main field number 106/57), 'Boya, WA' [315'ㄴ, 11603'E], A.K. Lee, 23 April 1957.

\section{Paratypes}

Not precisely known.

\section{Possible paratypes (69)}

R4425, Darkan, WA; R7004, R30422, R30529, R32793, R33066, R33171, R33357, R35159, Darlington, WA; R8453, nr Bullsbrook, WA; R11348, R11349*, R30413, Bickley, WA; R18562, R97588-90, 12 km E Kalamunda, WA; R19219, 6 mi [10 km] E Kalamunda, WA; R19646, Mundaring Weir, WA; R19821-22, 0.5 mi $[0.8 \mathrm{~km}] \mathrm{S}$ Pearce Aerodrome, WA; R21634-35, R30411-12，R30416，R30571，R33055，R33355-56, Boya, WA; R30409, R30417, R30421, R32491-93, R32781*, Caversham, WA; R30410, R32498, R32868, R33354, Swan View, WA; R30414, Greenmount-Red Hill Rd, WA; R30415, R32501, Sawyers Valley, WA; R30418, Red Hill Rd, WA; R30419, R33353, nr Boya, WA; R30420, Bakers Hill, WA; R30530, R32778, 4 mi [6 km] NE Beechina, WA; R32462, Beechina, WA; R32463, R32483-84, R35078-81, R35095-96, Red Hill, WA; R32481, R32650, John Forrest NP, WA; R32495, R32651-52, Middle Swan, WA; R33352, Greenmount, WA; R35052, Jarrahdale, WA; R38313, Walyunga Pool, WA; R97267, 1 mi [1.6 km] E Bullsbrook, WA.

\section{Remarks}

Holotype specimen has original the A.R. Main field tag still attached from when previously held by the UWA Zoology Department, 106/57. No paratypes were designated in the species description; however, Lee (1967) listed 38 specimens examined following the 'Description' and a further 64 specimens examined under 'Larvae and Juveniles', including broad localities and number of specimens examined from each category. Under 'Specimens examined' beneath the description heading, Lee (1967) stated 'Red Hill, 2 M, 1 F; Swan View, 1 M, 1F; Caversham, 3 M; Bakers Hill, 1 M; Sawyers Valley, 1 F; Darlington, 1 F; Greenmount 1; Boya, 18 M, 7 F; Bickley, 1 F'. Furthermore, under the Larvae and Juveniles heading, Lee lists an additional 64 specimens under specimens examined, including 'Larvae; Red Hill, 5; Greenmount, 46; Darlington, 2 
Juveniles; Jarrahdale, 6; Red Hill, 6'. Article 72. (b) and Recommendation 73D of the then current first edition of the International Code of Zoological Nomenclature (ICZN 1961; Article 72.4.1 and 72.4.5 of the current fourth edition of the Code (ICZN 1999), the 102 (101 excluding holotype) specimens listed as examined are considered paratypes.

The WAM collection contains 69 specimens (excluding the holotype) that would have been available to Lee at the time of the description, including 57 (excluding the holotype) formerly from the UWA collection with the A.R. Main field numbers; however, it is not known which of the 69 specimens were included as specimens examined and all are currently maintained as possible paratypes. Of the 69 possible paratypes, various life stages of the species are represented with the exception of larvae and juveniles which are poorly represented in contrast to the number of specimens listed by Lee. Despite the low number of larvae and juvenile specimens, it is possible many of the specimens used for the description were allowed to grow to various life stages before being euthanised and subsequently deposited at the WAM. Most of the 69 possible paratypes have more precise locality data than those presented by Lee 1967; however, many occur within the broad localities listed by Lee. There are also additional specimens of other Heleioporus species with the A.R. Main field numbers from the same localities as the possible paratypes which may have also been examined if unknown identification errors occurred.

Of the 69 possible paratype specimens in the WAM collection, two could not be located and are considered lost, R11349 and R32781. One is listed as 'gifted' (R11349) and the other as 'disposed' (R32781) on the WAM database, both without date or explanation as to reason for disposal or which institution the gifted specimen was sent. All extant possible paratypes in the WAM collection are the whole specimens stored in $70 \%$ ethanol solution, with the exception of R11348 which is a dry complete skeletal specimen. The single skeletal specimen was part of a series of whole specimens stored in $70 \%$ ethanol which were sent to the University of Adelaide in 1978 and were subsequently skeletonised and returned to WAM in 2014.

\section{Heleioporus inornatus Lee \& Main, 1954}

Lee, A.K. and Main, A.R. (1954) Two new species of burrowing frogs of the genus Heleioporus Gray from south-western Australia. Western Australian Naturalist 4(7): 156-158 [157].

\section{Holotype}

R11428 (formerly UWA Zoology Department collection, A.R. Main field number 155/54), 'Beechina, WA' [3149'S, 116²0'E], A.R. Main, 29 April 1954.

\section{Paratypes (20)}

Unknown.

\section{Possible paratypes (31)}

R21638-39, R32994, Beechina, WA; R30536, R30538, R32433, R32434, R32436, R32962, R3296568, R32973-74, R32976, R33054, R35009, R35075, R35083-84, R35089, R35121, $31 \mathrm{mi}$ [50 km] peg, Perth-Northam Rd [Great Eastern Hwy], WA; R32429, R32438, R32975, Sheepwash Creek, WA; R32435, 10 mi [16 km] E Dwellingup, WA; R32437, 8 mi [13 km] E Pinjarra, WA; R32439, 11 mi [18 km] E Pinjarra, WA; R32440, Sawyers Valley, WA; R33169, Gleneagle, WA.

\section{Remarks}

The holotype specimen was formerly held in the UWA Zoology Department collection prior to being deposited at the WAM (Anonymous 1961; Lee and Main 1954). In the early WAM hardcopy specimen register, the registration entry annotated with the A.R. Main field number 155/54 is R32675; however, the field tag is attached to the specimen registered as R11428. The specimen associated with the registration R32675 is H. eyrei from the ' $31 \mathrm{~m}$ peg, Perth-Northam Road, Beechina' and a loose tag (detached from specimen) with the A.R. Main field number $81 / 54$ can be matched to the specimen which has the string from the former field tag still attached.

No paratypes were designated in the species description; however, Lee and Main present average snout to cloaca measurements based on 18 males and 2 female specimens but do not provide any additional information on the specimens. Under Article 72.4.1 and 72.4.5 of the International Code of Zoological Nomenclature (ICZN 1999), the 20 (19 if holotype excluded) additional specimens are considered paratypes. Lee and Main mention that material used in the description was part of the UWA collection to be transferred to the WAM.

The WAM collection contains 36 specimens (excluding the holotype) that would have been available to Lee and Main at the time of the description, including 31 (excluding the holotype) formerly from the UWA collection with the A.R. Main field numbers; however, it is not known which of the 31 specimens were included as specimens examined and all are currently maintained as possible paratypes. There are multiple specimens of other Heleioporus species with the A.R. Main field numbers from the same localities as the possible paratypes which may have also been examined if unknown identification errors occurred. All but two possible paratypes are whole specimens stored in 70\% ethanol solution, R32965-66 are dry skeletal specimens. The two skeletal specimens were formerly whole specimens stored in $70 \%$ ethanol which were sent to the University of Adelaide in 1978 and were subsequently skeletonised and returned to WAM in 2014. 


\section{Heleioporus insularis Loveridge, 1933}

Loveridge, A. (1933) A new genus and three new species of crinine frogs from Australia. Occasional Papers of the Boston Society of Natural History 8: 89-94 [92].

Holotype

R4303, 'Rottnest Island, WA' [3200'S, $\left.115^{\circ} 31^{\prime} \mathrm{E}\right]$, L. Glauert, collection date unknown.

\section{Paratype}

R4289, Rottnest Is, WA.

\section{Current status}

Junior synonym of Heleioporus eyrei, fide Parker (1940) and Cogger et al. (1983).

\section{Remarks}

Five additional paratype specimens are in the MCZ: MCZ 18198-202.

\section{Heleioporus psammophilus Lee \& Main, 1954}

Lee, A.K. and Main, A.R. (1954) Two new species of burrowing frogs of the genus Heleioporus Gray from south-western Australia. Western Australian Naturalist 4(7): 156-158 [157].

\section{Holotype}

R11427 (formerly UWA Zoology Department collection, A.R. Main field number 364/54), 'Beechina,

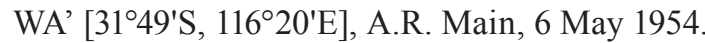

\section{Paratypes (20) \\ Unknown.}

\section{Possible paratypes (38)}

R21640, R30510, Beechina, WA; R30511-13, R30515, R30517，R30519-23，R30525-26，R30528，R32963, R32969，R32982-83，R32984*，R32985*，R32986*, R32987, R32989 $31 \mathrm{mi}$ [50 km] peg, Perth-Northam Rd [Great Eastern Hwy], WA; R30514, Walpole, WA; R30516, $257 \mathrm{mi}$ [414 km] peg, Perth-Geraldton Rd [Brand Hwy], WA; R30518, R32960, Sheepwash Creek, WA; R30524, R32961, R32990, Swan View, WA; R30527, R32993, 257 mi [414 km] peg, DongaraMingenew Rd [Midlands Rd], 15 mi [24 km] E Dongara, WA; R32849, Roes, WA; R32964, $31 \mathrm{mi}$ [50 km, in error] past Sheepwash Creek, WA; R32991, R33292, Lake Dalaroo, WA; R33168, Chidlow, WA.

\section{Remarks}

The holotype specimen was formerly held in the UWA Zoology Department collection prior to being deposited at the WAM (Anonymous 1961; Lee and Main 1954). No paratypes were designated in the species description; however, Lee and Main present average snout to cloaca measurements based on 18 males and 2 female specimens but do not provide any additional information on the specimens. Under Article 72.4.1 and 72.4.5 of the International Code of Zoological Nomenclature (ICZN 1999), the 20 (19 if holotype excluded in meristic data provided in the description) additional specimens are considered paratypes. Lee and Main mention that material used in the description was part of the UWA collection to be transferred to the WAM.

The WAM collection contains 38 specimens (excluding the holotype) with collection dates from 1954 or earlier, all of which were collected by Lee or Main and were formerly in the UWA collection with the A.R. Main field numbers; however, it is not known which of the 38 specimens were included as specimens examined and all are currently maintained as possible paratypes. With the exception of two specimens (R32982-83), all possible paratypes are whole specimens stored in $70 \%$ ethanol solution, R32982-83 dry skeletal specimens. Both skeletal specimens are formerly whole specimens stored in $70 \%$ ethanol sent to the University of Adelaide in 1978 which were subsequently skeletonised and returned to WAM in 2014. One possible paratype specimen (R32985) is listed as destroyed on the WAM database with no additional information or reasoning provided. Two possible paratype specimens (R32984 and R32986) are listed as missing on the WAM database and have not been sighted since May 1998; both specimens could not be located and are presumed lost.

\section{Limnodynastes depressus Tyler, 1976}

Tyler, M.J. (1976) A new genus and two new species of leptodactylid frogs from Western Australia. Records of the Western Australian Museum 4(1): 45-52 [50].

\section{Holotype}

R43896, 'near former Argyle Downs homestead, Ord River, WA' [16 $\left.16^{\circ} \mathrm{S}, 128^{\circ} 48^{\prime} \mathrm{E}\right]$, Western Australian Museum survey party, 12 January 1972.

\section{Remarks}

A tag associated with the type specimen states collection as 'vicinity of old Argyle Downs Homestead, Ord River, WA'. The type specimen was collected as part of 'Operation Noah' when the waters began to rise at the completion of the Ord River dam in 1971, forming Lake Argyle (Ron Johnstone, personal communication, 2016). The type location is currently completely submerged below the lake.

\section{Megistolotis lignarius Tyler, Martin \& Davies, 1979}

Tyler, M.J., Martin, A.A. and Davies, M. (1979) Biology and systematics of a new limnodynastine genus (Anura: Leptodactylidae) from north-western Australia. Australian Journal of Zoology 27: 135-150 [137]. 


\section{Holotype}

R58299, 'adjacent to the Lake Argyle-Kununurra road, $6.5 \mathrm{~km} \mathrm{~N}$. of Lake Argyle Tourist Village, Lake Argyle, Kimberley Division, WA' [16 $\left.02^{\prime} \mathrm{S}, 128^{\circ} 47^{\prime} \mathrm{E}\right]$, M. Davies, A.A. Martin and M.J. Tyler, 20 February 1977.

\section{Paratypes (3)}

R42398, Kalumburu, WA; R50891, Drysdale River NP, WA; R58881, 5.2 km S Beta Creek, WA.

\section{Current nomenclature}

Limnodynastes lignarius, see Schäuble et al. (2000).

\section{Remarks}

Additional paratype specimens are held in other collections: 15 at SAMA (SAMA R16228-29, R1631625, R16377, R16608-09), seven at NTM (including 2 formerly from AZRI-CAM collection; NTM R578-79, R642, R2143, R5035, R31043 (formerly AZRI-CAM A121), R31044 (formerly AZRI-CAM A122), four at AMS (AMS R38999-9000, R46127, R61485), one at BMNH (BMNH 1977.517) and one at KU (KU 175514) (Tyler et al. 1979).

\section{Neobatrachus albipes Roberts, Mahony, Kendrick \& Majors, 1991}

Roberts, J.D., Mahony, M., Kendrick, P. and Majors, C.M. (1991) A new species of burrowing frog, Neobatrachus (Anura: Myobatrachidae), from the eastern wheatbelt of Western Australia. Records of the Western Australian Museum 15(1): 23-32 [24].

\section{Holotype}

R101178 [in error, R101182], ' 4.2 km N Hopetoun, WA $\left(33^{\circ} 54^{\prime} \text { S, } 120^{\circ} 08^{\prime} \mathrm{E}\right)^{\prime}$, J.D. Roberts and P. Kendrick, 3 May 1988.

\section{Paratypes (15)}

R36291, 41.6 km E Southern Cross, WA; R39841, Greenshield Soak, nr Lake Magenta, WA; R49800, Dongolocking NR, WA; R52546, R52550, Badjaling NR, 11 km E Quairading, WA; R65144, 0.6 km W Lake Cronin, WA; R93378, Junana Rock, Cape Arid NP, WA; R94796, Lake Magenta NR, WA; R96779, Fitzgerald River NP, WA; R101179-80, R101185, 20.5 km E Jerramungup, WA; R101183-84, Pallarup Rocks, 44.6 km NE Ravensthorpe, WA; R101186, Yoting, WA.

\section{Remarks}

The holotype (R101178) listed by Roberts et al. (1991) is in error; R101178 is a specimen of Neobatrachus pelobatoides collected from $20.5 \mathrm{~km} \mathrm{~W}$ Jerramungup, WA and does not match the morphological description given for $N$. albipes (Roberts 2010). Roberts (2010) determined the true holotype for $N$. albipes as specimen R101182 which correctly matched the morphology and locality presented in the description, identified by the call recording collected in the field for the holotype (Frog \#3, JDR Tapes 79 and 80). Holotype calls recorded and described in the species description (Frog \#3, JDR Tapes 79 and 80) are currently housed in the CENRM. Liver sample of one paratype (R101180) stored at the EBU.

\section{Neobatrachus aquilonius Tyler, Davies \& Martin, 1981}

Tyler, M.J., Davies, M. and Martin, A.A. (1981) New and rediscovered species of frogs from the Derby-Broome area of Western Australia. Records of the Western Australian Museum 9(2): 147-172 [155].

\section{Holotype}

R71005, '22-41 km S of Derby, Kimberley Division, WA' [17³0'S, $123^{\circ} 44^{\prime}$ E], A.H. Cross, M. Davies, A.A. Martin and M.J. Tyler, 14 February 1980.

\section{Paratypes (9)}

R62195, 32 km S Derby, WA; R71001-04, R71006-09, 10-41 km S Derby, WA.

\section{Remarks}

Of the additional eight paratypes presented in the description, seven are in SAMA (SAMA R18012-14, R18032-33, R18101-02) and one in BMNH (BMNH 1979.729).

\section{Neobatrachus fulvus Mahony \& Roberts, 1986}

Mahony, M.J. and Roberts, J.D. (1986) Two new species of desert burrowing frogs of the genus Neobatrachus (Anura: Myobatrachidae) from Western Australia. Records of the Western Australian Museum 13(1): $155-170$ [157].

\section{Holotype}

R52994, 'Exmouth, near North West Cape, WA $\left(21^{\circ} 56^{\prime} \mathrm{S}, 1^{\circ} 4^{\circ} 07^{\prime} \mathrm{E}\right)^{\prime}, \mathrm{G}$. Harold and G. Barron, 8 March 1976.

\section{Paratypes (10)}

R52937-42, Exmouth, WA; R76583, 18 km E Gnaraloo, WA; R93494-96, Learmonth, WA.

\section{Remarks}

Two additional paratypes are held in AMS: AMS R119438-39. A loose label associated with the holotype states 'Neobatrachus centralis, collected by G. Harold and G. Harold [in error, G. Barron] from Exmouth light aircraft landing strip'. Call structure for this species reported in the type description was from a single frog on a cassette recording - details reported in Mahony and Roberts (1986). Current status of original recording is unknown. 


\section{Neobatrachus kunapalari Mahony \& Roberts, 1986}

Mahony, M.J. and Roberts, J.D. (1986) Two new species of desert burrowing frogs of the genus Neobatrachus (Anura: Myobatrachidae) from Western Australia. Records of the Western Australian Museum 13(1): $155-170$ [163].

\section{Holotype}

R93485, ' $8.9 \mathrm{~km} \mathrm{~S}$ of Merredin, WA $\left(31^{\circ} 33^{\prime} \mathrm{S}\right.$, $\left.118^{\circ} 15^{\prime} \mathrm{E}\right)^{\prime}$, J.D. Roberts and D. Cale, 26 May 1985.

\section{Paratypes (8)}

R93486-92, 7-18 km S Merredin, WA; R93493, 15.1 km SSW Narembeen, WA.

\section{Remarks}

Three additional paratypes are held in AMS: AMS R119436-37 and R118104. The holotype and six WAM paratypes were previously held in AMS but were not formally registered with the AMS R prefix. The former AMS specimens have A.M. herpetology field (A.M. Herp) numbers still attached; holotype R93485 (formerly A.M. Herp 35694) and paratypes R93486 (A.M. Herp 35672), R93487 (A.M. Herp 35681), R93488 (A.M. Herp 35682), R93489 (A.M. Herp 35695), R93490 (A.M. Herp 35691), R93491 (A.M. Herp 35692) and R93492 (A.M. Herp 35693). Mahony and Roberts (1986) stated 'call data are available from two paratypes and from two other frogs' and provided a description of the species mating call, supplemented with an oscillogram. Of the eight paratypes, five are males and it is not known which individuals the call recordings are associated with.

\section{Neobatrachus sutor Main, 1957}

Main, A.R. (1957) A new burrowing frog from Western Australia. Western Australian Naturalist 6(1): 23-24 [24].

\section{Holotype}

R32892 (formerly UWA Zoology Department collection, A.R. Main field number 22/57), 'Gnoolowa Hill, 18 miles [29 km] north of Mingenew', WA [285' S, 115²6'E], A.R. Main, 18 March 1957.

\section{Paratype}

R32893 (formerly UWA Zoology Department collection, A.R. Main field number 21/57), Gnoolowa Hill, 18 miles [28.9 km] N Mingenew, WA.

\section{Remarks}

Holotype and allotype (now considered a paratype) formerly held in the Zoology Department Collection, University of Western Australia, registration numbers 22/57 (R32892) and 21/57 (R32893) prior to being transferred to the WAM. Western Australian Museum registration numbers were identified from examination of accession data for the two specimens matching Main's specimen field numbers given in the description. The allotype specimen listed by Main (R32893) is considered a paratype here under Article 72.4.6 of International Code of Zoological Nomenclature (ICZN 1999).

\section{Notaden weigeli Shea \& Johnston, 1988}

Shea, G.M. and Johnston, G.R. (1988) A new species of Notaden (Anura: Leptodactylidae) from the Kimberley Division of Western Australia. Transactions of the Royal Society of South Australia 112: 29-37 [29].

\section{Holotype}

R77149, 'Sandstone Ck [in error, Camp Ck, Mitchell Plateau], WA (1453'30"S, $\left.125^{\circ} 45^{\prime} 00^{\prime \prime} \mathrm{E}\right)$ ', C. Kemper, 26 October 1981.

\section{Paratypes (3)}

R83428-29, 23 km NW old Mount Elizabeth HS, WA; R100216 (formerly AMS R123896), Mitchell Plateau, WA.

\section{Remarks}

The 1987 publication date listed in the citation summary at the beginning of the paper is in error; the correct publication data is 31 May 1988 as stated at the end of the citation summary. The holotype locality of Sandstone Creek is in error; the specimen was in fact collected from Camp Creek, Mitchell Plateau. 'Sandstone Creek' was in reference to the description of the collection site which was also provided when the specimen was accessioned (Laurie Smith, personal communication, 2016). The incorrect locality information was erroneously presented on specimen loan documentation provided to the author and subsequently presented in the description (Glenn Shea, personal communication, 2016). One paratype formerly held at AMS (AMS R123896) was gifted to WAM following the description (R100216). A further three paratypes are held in AMS: AMS R123897-99.

\section{Family Myobatrachidae}

\section{Arenophryne rotunda Tyler, 1976}

Tyler, M.J. (1976) A new genus and two new species of leptodactylid frogs from Western Australia. Records of the Western Australian Museum 4(1): 45-52 [46].

\section{Holotype}

R39120, '100 m from False Entrance Well Tank, Carrarang Station, $320 \mathrm{~km} \mathrm{NNW}$ of Geraldton, WA $\left(26^{\circ} 23^{\prime} \mathrm{S}, 113^{\circ} 18^{\prime} \mathrm{E}\right)^{\prime}$, A. Baynes and T.A. Smith, 24 August 1970.

\section{Paratypes (8)}

R39115-19, R39121-23, False Entrance Well, Carrarang Stn, WA. 


\section{Remarks}

Tags associated with the holotype initialled with M.J.T. state 'Arenophryne globosa' (the previous working name; Michael Tyler, personal communication, 2016) with collection data as presented in the description; however, it is dated '22:VIII:1970'. An additional paratype is held in SAMA (SAMA R14521).

\section{Arenophryne xiphorhyncha Doughty \& Edwards, 2008}

Doughty, P. and Edwards, D. (2008) A new species of Arenophryne (Anura: Myobatrachidae) from the central coast of Western Australia. Records of the Western Australian Museum 24: 121-131 [122].

\section{Holotype}

R67321, 'Cooloomia Station, WA (2701'S, 114 $\left.{ }^{\circ} 19^{\prime} \mathrm{E}\right)$ ', J. Rolfe, S.D. Hopper, P.J. Fuller and K. Cashin, 19 September 1979.

\section{Paratypes (10)}

R67320, R67323, Cooloomia Stn, WA; R123485, R123554, R126245, R126251, R126261, R126270, 50 km N Kalbarri, WA; R165815, Sandy Junga Pits, WA; R165821, 10 km NW Murchison House Stn, WA.

\section{Remarks}

Liver sample of two paratypes (R165815, R165812) stored in $100 \%$ ethanol solution at the WAM.

\section{Crinia fimbriata Doughty, Anstis \& Price, 2009}

Doughty, P., Anstis, M. and Price, L.C. (2009) A new species of Crinia (Anura: Myobatrachidae) from the high rainfall zone of the northwest Kimberley, Western Australia. Records of the Western Australian Museum 25: 127-144 [137].

\section{Holotype}

R167743, 'Little Mertens Falls, Mitchell Plateau, WA (14'49'20"S, 125'42'39"E)', L. Price and J. Francis, 7 January 2007.

\section{Paratypes (8)}

R163823, 5.2 km SW Prince Regent River and Pitta Creek Junction, WA; R167744-45, Little Mertens Falls, Mitchell Plateau, WA; R159800-02, R159803*, Mitchell Plateau, WA; R159804, Prince Regent River NR, WA.

\section{Remarks}

Registration numbers were allocated to some paratype specimens in life that were maintained in captivity for a period for the description. R159803 was a tadpole that died in captivity and became partially decomposed. After preservation it was in poor condition and was disposed of. Despite being listed as a paratype, this specimen was not included in the individuals examined that formed the descriptions (Marion Anstis, personal communication, 2016). Of the seven paratypes in the WAM collection, three are adult or metamorph specimens (R163823, R167744, R167745) and four are larvae (R159800-02, R159804). One additional paratype is held in SAMA (SAMA R62994). Liver sample of the holotype and three paratypes (R163823, R167744-45) stored in $100 \%$ ethanol solution at the WAM.

\section{Crinia glauerti Loveridge, 1933}

Loveridge, A. (1933) Four new crinine frogs from Australia. Occasional Papers of the Boston Society of Natural History 8: 55-60 [57].

\section{Paratype}

R4583*, Mundaring Weir, WA.

\section{Remarks}

Under paratypes, Loveridge (1933) listed registration numbers of two specimens from the MCZ collection (MCZ 18421-22) and stated two additional specimens were donated to the WAM and AMS (AMS R10910), both with the same collection details as the holotype. Holotype housed in the MCZ collection: MCZ 18420, from 'Mundaring Weir, about thirty miles [48 km] northeast of Perth, West Australia' [31 $57^{\circ} \mathrm{S}, 116^{\circ} 09^{\prime} \mathrm{E}$ ], collected by P.J. Darlington, 22 November 1931. The paratype could not be located and has not been sighted in audits dating back to October 1998; the specimen is presumed lost.

\section{Crinia lutea Main, 1963}

Main, A.R. (1963) A new species of Crinia (Anura; Leptodactylidae) from National Park, Nornalup. Western Australian Naturalist 8(6): 143-144 [143].

\section{Holotype}

R17616, 'shallow valley on left bank of Deep River on western boundary of Nornalup National Park [Walpole Nornalup National Park], where the Manjimup to

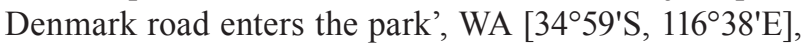
A.R. Main, 23 October 1962.

\section{Paratypes (9)}

Unknown*, Deep River, WA.

\section{Current nomenclature}

Geocrinia lutea, see Blake (1973).

\section{Remarks}

No paratypes were designated in the species description; however, Main states 'Other specimens examined; males 2, females 2, juv. 4' in the text and mentions multiple collecting events at the type locality in the introduction. Under Article 72. (b) and 
Recommendation 73D of the then current first edition of the International Code of Zoological Nomenclature (ICZN 1961; Article 72.4.1 and 72.4.5 of the current fourth edition of the Code (ICZN 1999), the nine additional specimens are considered paratypes. No additional specimens matching the collection or locality data presented in the original description could be located in the WAM collection and all nine paratypes are considered lost.

\section{Crinia parinsignifera Main, 1957}

Main, A.R. (1957) Studies in Australian Amphibia 1. The genus Crinia Tschudi in south-western Australia and some species from south-eastern Australia. Australian Journal of Zoology 5: 30-55 [53].

\section{Holotype}

R38735 (formerly UWA Zoology Department collection, A.R. Main field number 431/55), 'Kingstonon-Murray', SA, [341' S, $\left.140^{\circ} 21^{\prime} \mathrm{E}\right]$, A.R. Main, 18 August 1955.

\section{Paratypes (9)}

R38245，R38728，R38733，R38736，R38738-39, Kingston-on-Murray, SA; R38730, R38734, R38737, 7 mi $[11 \mathrm{~km}] \mathrm{N}$ Horsham, Vic.

\section{Remarks}

Holotype formerly held in the Zoology Department Collection, UWA, with the A.R. Main field tag (431/55) prior to being transferred to WAM. No paratypes were designated in the species description; however, Main lists 25 specimens under specimens examined from Blanchetown, SA (1), Kingston-on-Murray, SA and 7 miles north of Horsham, Vic. but does not provide any additional information on these specimens. Under Article 72. (b) and Recommendation 73D of the then current first edition of the International Code of Zoological Nomenclature (ICZN 1961; Article 72.4.1 and 72.4.5 of the current fourth edition of the Code (ICZN 1999), the 25 (24 if holotype excluded) additional specimens are considered paratypes. Main stated that all examined material was collected by himself and held in the UWA Zoology Department collection. He did not indicate if all specimens were deposited at WAM or some were maintained at UWA.

Of the 24 specimens (excluding the holotype) listed as examined by Main, only nine specimens matching the locality data are held in the WAM collection, six from Kingston-on-Murray, S.A. and three from 7 miles north of Horsham, Vic. No specimens associated with the locality Banchetown, SA could be located; however, it is not known if these and the remaining 15 specimens listed by Main were deposited at the WAM or another institution and their current whereabouts are unknown. The 15 additional paratypes that cannot be located are presumed lost.

\section{Crinia pseudinsignifera Main, 1957}

Main, A.R. (1957) Studies on Australian Amphibia 1. The genus Crinia Tschudi in south-western Australia and some species from south-eastern Australia. Australian Journal of Zoology 5: 30-55 [52].

\section{Holotype}

R36153 (formerly UWA Zoology Department collection, A.R. Main field number 1000/54), 'Yorkarakine Rock, 15 miles [24 km] north of Tammin, WA' [31 $\left.25^{\prime} \mathrm{S}, 117^{\circ} 31^{\prime} \mathrm{E}\right]$, A.R. Main, 19 July 1954.

\section{Paratypes (233)}

Unknown, Nebree Spring, WA $(\mathrm{N}=3)$; Koodiwoodie, WA $(\mathrm{N}=16)$; Dongara, WA $(\mathrm{N}=7)$; Chittering, WA $(\mathrm{N}=7)$; Bullsbrook, WA $(\mathrm{N}=3)$; Red Hill, WA $(\mathrm{N}=$ 3); Walyunga, WA $(\mathrm{N}=3)$; Helena Valley, WA $(\mathrm{N}=8)$; Mundaring, WA $(\mathrm{N}=5)$; Darlington, WA $(\mathrm{N}=3)$; Boya Quarry, WA $(\mathrm{N}=22)$; Beechina, WA $(\mathrm{N}=42)$; Clackline, WA $(\mathrm{N}=1)$; Northam, WA $(\mathrm{N}=1)$; Quairading, WA ( $\mathrm{N}$ =7); Waeel, WA $(\mathrm{N}=1)$; Yorkrakine Rock, WA $(\mathrm{N}=21)$; Moorine Rock, WA ( $=3)$; Kwolyin, WA $(\mathrm{N}=18) ; 217$ mi [349 km] post, Albany Rd [Hwy], WA ( $\mathrm{N}=3)$; Lake Muir, WA $(\mathrm{N}=5)$; Yallingup turnoff, Dunsborough, WA ( $=1)$; Augusta-Nannup Rd, WA $(\mathrm{N}=15)$; Stirling Ranges, WA $(\mathrm{N}=15) ; 8 \mathrm{mi}[13 \mathrm{~km}] \mathrm{E}$ Jarramongup [Jerramungup], WA $(\mathrm{N}=2)$; Peak Charles, WA $(\mathrm{N}=$ 2); Doubtful Island Bay, WA $(\mathrm{N}=1) ; 18 \mathrm{mi}[29 \mathrm{~km}] \mathrm{W}$ Ravensthorpe, WA ( $\mathrm{N}=5) ; 5 \mathrm{mi}$ [8 km] E Ravensthorpe, WA $(\mathrm{N}=1)$; Junana Rock and Pine Hill, WA $(\mathrm{N}=5)$; Dempster's Head, Esperance, WA $(\mathrm{N}=4)$.

\section{Possible paratypes (229)}

R825-26, Moingup Pass, Stirling Range, WA; R968-72, R39263, R39349, Darlington, WA; R1912-14, Lower Chittering, WA; R30269, R38677-78, R39307, R39316, R39354, Beechina, WA; R34900, R35913-20, R38746, R38749, R39260, R39272, Stirling Range, WA; R35362-66, R35848, R35396, Koodiwoodie Creek, Dandaragan, WA; R35385, R35430, R38807-09, R39309-10, R39323, R39326-28, R39330-34, R3933648, R39350, R39353, R39356-58, R39398, 31 mi [50 km] peg, Perth-Northam Rd, Beechina, WA; R35693, R39373-74, Moorine Rock, WA; R35961-64, Junana Rock, WA; R35965, Pine Hill, WA; R38210, R38663, R39368, Helena Valley, WA; R38211-16, Red Hill Rd, WA; R38241, R38628, R38656-57, Peak Charles, WA; R38246,0.5 mi [0.8 km] W Lake Muir, WA; R38498*, Yorkrakine Hill, WA; R38632-34, R38643-45,18 mi [29 km] W Ravensthorpe turnoff, WA; R38648-54, R38658, R38659-61, R39433, Dempster's Head, Esperance, WA; R38664, R38666-70, Koodiewoodie, WA; R38745, 116 mi [187 km] peg, Albany Hwy, WA; R38748, R39255-56, R39267, R39269, 6 km SE Toolbrunup Peak, Stirling Range NP, WA; R38788-805, R38806*, Kwolyin, WA; R38810-14, R38817-21, R39335, R39351, R39359-64, Yorkrakine Rock, WA; R38822，R39311-14，R39322，R39385，R39387-91, Augusta-Nannup Rd, WA; R39251-54, Chittering 
Brook, WA; R39261, Swamp SE of Chittering Pass, WA; R39278, Chittering Lakes, WA; R39281, nr Yallingup turnoff, Dunsborough, WA; R39282, $5 \mathrm{mi}[8$ km] E Ravensthorpe, WA; R39283-97, quarry at Boya, WA; R39298-300, Quairading, WA; R39303, Northam, WA; R39304-05, 8 mi [13 km] E Jerramungup, WA; R39306, R39366-67, R39370-72, Irwin River, Dongara, WA; R39315, R39324, Albany Hwy, Kendenup, WA; R39318-21, Quairading Spring, WA; R39329, Clackline, WA; R39352, Waeel, WA; R39355, R39369, Red Hill, WA; R39365, Doubtful Island Bay, WA; R39378-81, Mundaring, WA; R39382-84, R39386, Dammed Creek, Helena Valley, WA.

\section{Remarks}

Holotype formerly held in the Zoology Department collection, UWA, with the A.R. Main field tags attached $(1000 / 54)$ prior to being transferred to WAM. No paratypes were designated in the species description; however, Main lists 234 specimens (presumably including the holotype) from 32 localities under specimens examined (p. 52), see above for localities and number of the specimens from each with one specimen from Yorarakine Rock (presumably holotype) excluded. In accordance with Article 72.4.1 and 72.4.5 of the current fourth edition of the Code (ICZN 1999), the 234 (233 if holotype excluded) additional specimens are considered paratypes. Main did not state if specimens examined would be deposited at the WAM and it is not known if all specimens were subsequently deposited at the WAM, other institutions or disposed of following the description.

A total of 337 specimens in the WAM collection from various locations would have been available to Main for the description, of which 229 match locality data presented in the description including 178 collected by Main. The WAM collection holds 47 specimens matching the localities and associated number of specimens presented by Main for 14 localities from; Nebree Spring $(\mathrm{N}=3)$, Clackline $(\mathrm{N}=1)$, Northam $(\mathrm{N}=$ 1), Quairading $(\mathrm{N}=7)$, Waeel $(\mathrm{N}=1)$, Moorine Rock ( $\mathrm{N}$ =3), Kwolyin $(\mathrm{N}=18), 217 \mathrm{mi}$ [349 km] post Albany Rd [Hwy] $(\mathrm{N}=3)$, Yallingup turnoff, Dunsborough $(\mathrm{N}=1), 8$ mi $[13 \mathrm{~km}]$ E Jerramungup $(\mathrm{N}=2)$, Doubtful Island Bay $(\mathrm{N}=1), 5 \mathrm{mi}[8 \mathrm{~km}]$ E Ravensthorpe $(\mathrm{N}=1)$, Juana Rock and Pine Hill $(\mathrm{N}=5)$. The WAM collection also holds more than the number of specimens listed by Main for some locality records including Chittering, Red Hill, Darlington, Stirling Ranges, Peak Charles, 18 mi [29 km] W Ravensthorpe and Dempster's Head, Esperance. As the specific specimens examined by Main cannot be identified, all specimens are maintained as possible paratypes. The number of specimens in the WAM collection matching some localities listed by Main does not total the number of specimens associated with each listed by Main; Koodiwoodie (10 of 16), Dongara (6 of 7), Bullsbrook (0 of 3), Walyunga (0 of 3), Helena Valley (7 of 8), Mundaring (4 of 5), Boya Quarry (15 of 22), Beechina (41 of 42), Yorkrakine Rock (20 of 22), Lake Muir (1 of 5), Augusta-Nannup Rd (12 of 15). As it is not known which, if any, of the specimens held in the WAM collection matching the locality data presented by Main are in fact specimens examined by Main, all specimens are currently maintained as possible paratypes. The additional specimens of some localities referred to by Main that could not be identified or located in the WAM collection are presumed lost. Two possible paratypes, R38498 and R38806, could not be located and have not been sighted in audits dating back to July 1998; both specimens are presumed lost.

\section{Crinia rosea Harrison, 1927}

Harrison, L. (1927) Notes on some Western Australian frogs, with descriptions of two new species. Records of the Australian Museum 15: 277-287 [279].

\section{Paratypes}

Unknown.

\section{Current nomenclature}

Geocrinia rosea, see Blake (1973).

\section{Remarks}

Harrison (1927) reported eight individuals used in the description, all collected from the type locality 'Pemberton, in Karri country, 218 miles [351 km] south of Perth', WA [3426'S, $116^{\circ} 03^{\prime} \mathrm{E}$ ], 28 August 1926. In the description for the species under 'Types' Harrison states 'Holotype female and allotype male in the Macleay Museum of the University of Sydney. Paratype material will be distributed to the Western Australian Museum, Perth, the Australian Museum, Sydney, the British Museum (Natural History), and the American Museum of Natural History.' However, there are no specimens in the WAM collection matching the type information provided, or any record of specimens being received by the WAM.

Shea and Sadlier (1999) reported there was no evidence that type specimens of $C$. rosea were received or held in the collection of MMUS, AMS or WAM and Cogger et al. (1983) reported syntypes not found for this or the other species described in the same publication (Pseudophryne nichollsi Harrison, 1927). In Parker's (1940) monograph on leptodactylid frogs, he lists a single specimen examined: MCZ 18419 from the type locality; however, the specimen is part of a series collected by P.J. Darlington in 1931 (Loveridge 1935) and postdates the species description. Cogger (1979) stated primary herpetological types of the MMUS were given to the AM on permanent loan in 1969; however, no types for $C$. rosea were listed. 
In a list of herpetological type specimens in the MMUS, Goldman et al. (1968) list seven amphibian types; however, this does not include types for $C$. rosea or Pseudophryne nichollsi Harrison, 1927 and there is no mention of the species at all. Goldman et al. (1968) stated 'several types appear to have been lost' which was attributed to the museum's history within the Macleay Building. Namely, as a result of the collection being moved on multiple occasions to various parts of the Macleay Building, including a period during which it was sealed in the attic, and periods where the collection often suffered from a lack of access and inadequate management (Glenn Shea, personal communication, 2016). During periods of inadequate curatorship many specimens in spirit preservative, particularly amphibians and reptiles, dried out (Goldman et al. 1968; Horning 1993; van der Valk 1984). In a later catalogue of the amphibian specimens in the MMUS (van der Valk 1984), there is also no mention of C. rosea or Pseudophryne nichollsi.

There is no record or evidence of any type specimens of C. rosea at the AMS (Shea and Sadlier 1999; Glenn Shea, personal communication, 2016), AMNH (David Dickey, personal communication, 2016) or BMNH (Jeff Streicher, personal communication, 2016). Parker (1940) made no reference to any specimens matching the information for types provided by Harrison in a subsequent publication on Australian frogs. Numerous searches of WAM specimens and records including accession data have failed to locate any evidence of any type specimens for the species. It is likely the specimens were never deposited or distributed to any of the museums listed in the description, and were instead disposed of or lost following Harrison's unexpected death only a year after the description of C. rosea and P. nichollsi in early 1928 (Glenn Shea, personal communication, 2016).

\section{Crinia subinsignifera Littlejohn, 1957}

Littlejohn, M.J. (1957) A new species of frog of the genus Crinia. Western Australian Naturalist 6(1): 18-23 [22].

\section{Holotype}

R12786 (formerly UWA Zoology Department collection, A.R. Main field number 367/56), 'swamps by the 181 mile peg on the main Perth to Pemberton road at Wilgarup, $7 \mathrm{mi}$ [11 km] north of Manjimup', WA [3408'S, 116²10'E], M.J. Littlejohn, 14 July 1956.

\section{Paratypes (34)}

Unknown, Wilgarup, WA $(\mathrm{N}=15) ; 15$ miles [24 km] N Mt. Barker Warriups Rd. [in error] $(\mathrm{N}=8)$; [Warriup Rd.,] 4 miles [6 km] E Cheyne Beach turn-off $(\mathrm{N}=12)$.

\section{Possible paratypes (25)}

R38958-66, $181 \mathrm{mi}$ [291 km] peg, Wilgarup, WA; R39209-24, 1 mi [1.6 km] W Warriup Rd. turnoff, WA.

\section{Remarks}

A label associated with the holotype reads 'M.T. Littlejohn' as source and '14.7.1956' as collection date. Holotype formerly held in the collection of the UWA Zoology Department, the A.R. Main field number $367 / 56$ prior to being transferred to WAM (Anonymous 1961; Littlejohn 1957). Call recordings of the holotype specimen were collected and described in the species description. An analogue recording (tape) and oscillograms of the recording were deposited with the holotype; however, neither recordings nor oscillograms could be located after the 2004 move of collections and are considered lost. In referring to the type specimens, Littlejohn states 'to be transferred to the Western Australian Museum'; however, there is no mention of any other material examined being deposited at the WAM.

No paratypes were designated in the species description; however, Littlejohn presents body lengths for 35 specimens (presumably including the holotype) from 'Waligarup' $(\mathrm{N}=15)$, '15 miles [24 km] north of Mt. Barker Warriups Rd., [in error]' $(\mathrm{N}=8)$ and '[Warriup Rd.], 4 miles [6 km] east of Cheyne Beach turn-off' $(\mathrm{N}=12)$ but does not provide any additional information regarding specimens. One locality presented by Loveridge ' 15 miles [24 km] north of Mt. Barker Warriups Rd.', is in error; 'Warriups [Warriup] Rd.,' is associated with the following locality ' 4 miles [6 km] east of Cheyne Beach turn-off'. In accordance with Article 72.4.1 and 72.4.5 of the fourth edition of the Code (ICZN 1999), the 34 (35 if holotype included) additional specimens are considered paratypes. The WAM collection contains 25 specimens (excluding the holotype) closely matching locality data presented in the description that would have been available to Littlejohn at the time of the description, including 16 (excluding the holotype) formerly from the UWA collection; however, it is not known which of the 25 specimens were included as specimens examined and all are currently maintained as possible paratypes. Of the 25 specimens in the WAM collection, 16 are from ' $1 \mathrm{mi}$ [1.6 km] W Warriup turnoff, WA' and nine from ' $181 \mathrm{mi}$ [291 km] peg, Wilgarup, WA'. No specimens associated with the locality ' 15 miles north of Mt. Barker' could be located; however, it is not known if these and other specimens examined by Littlejohn were deposited at the WAM, another institution or possibly disposed of and their current whereabouts are unknown. Nine of the additional specimens referred to by Littlejohn that could not be identified or located are presumed lost. There are also additional specimens of other Crinia species collected by Littlejohn from the same localities as the possible paratypes which may have also been examined if unknown identification errors occurred. 


\section{Geocrinia alba \\ Wardell-Johnson \& Roberts, 1989}

Wardell-Johnson, G. and Roberts, D. (1989) Endangered! Forest frogs. Landscope 5(1): 17 [17].

\section{Lectotype}

R94466, 'Bruce Road, $11.5 \mathrm{~km} \mathrm{~S}$ of Witchcliffe, WA (34 $\left.03^{\prime} \mathrm{S}, 115^{\circ} 10^{\prime} \mathrm{E}\right)^{\prime}$, G. Wardell-Johnson and J.D. Roberts, 15 November 1985.

\section{Paralectotypes (18)}

R94457*, R95955-62, R95964-72, Bruce Road, 11.5 km S Witchcliffe, WA.

\section{Remarks}

The species, along with $G$. vitellina, was first presented as a new species with diagnostics (ventral colouration) to diagnose them from their congeners by Wardell-Johnson and Roberts (1989) in the popular glossy-paged magazine Landscope published by the Department of Conservation and Land Management (now Department of Parks and Wildlife). Because a name was proposed accompanied by diagnostic characters, this was sufficient at the time to qualify as a valid description in zoology under the International Code of Zoological Nomenclature, then third edition (ICZN 1985). This was not known by the senior author due to the differences in valid description criteria between the International Code of Zoological Nomenclature and the International Code of Botanical Nomenclature, the author's area of expertise. A holotype was not nominated in the magazine article; thus no information was provided on the type series. The 'original description' was focused on 'drawing attention to their urgent need for conservation' and not to provide a full description of the species (Roberts et al. 1990). An extended description and nomination of type specimens was presented by Roberts et al. (1990) where they listed the intended type series and designated a lectotype. In the extended description of the species, Roberts et al. (1990) provided a description of the species call, supplemented with a sound spectrogram. The call description was based on 19 analogue recordings from the lectotype and paralectotype (JDR tapes 66 and 67; JDR cassette No. 7), currently held at CENRM. One paralectotype (R94457) could not be located and has not been sighted in audits dating back to October 1998; the specimen is presumed lost.

\section{Geocrinia vitellina Wardell-Johnson \& Roberts, 1989}

Wardell-Johnson, G. and Roberts, D. (1989) Endangered! Forest frogs. Landscope 5(1): 17 [17].

\section{Lectotype}

R94467, 'intersection of Spearwood Creek and Denny road, $20.4 \mathrm{~km}$ ESE Witchcliffe, WA (34ํํㄴ' $\left.\mathrm{S}, 115^{\circ} 19^{\prime} \mathrm{E}\right)$ ', G. Wardell-Johnson and D. Roberts, 15 November 1985.

\section{Paralectotypes (12)}

R86472-83, Spearwood Creek, 20.4 km ESE Witchcliffe, WA.

\section{Remarks}

This species, along with G. alba, was first presented as a new species by Wardell-Johnson and Roberts (1989) in the popular glossy-paged magazine Landscope. Although the publication did not provide a full description of the species, nor nomination of type material, the name was proposed with sufficient accompanying diagnostics, to qualify at the time as a valid description in zoology under the International Code of Zoological Nomenclature, then third edition (ICZN 1985); see account for G. alba above. As for G. alba, Roberts et al. (1990) presented an extended description including call descriptions in addition to identifying the syntype series and nominating a lectotype for the species. The call description was based on 15 recordings of which eight were from paralectotype specimens (R86472-79). Analogue recordings are currently held at CENRM.

\section{Glauertia russelli Loveridge, 1933}

Loveridge, A. (1933) A new genus and three new species of crinine frogs from Australia. Occasional Papers of the Boston Society of Natural History 8: 89-94 [89].

\section{Holotype}

R2608, 'bank of a creek [Aurillia Creek] flowing into Gascoyne River near Landor Station, WA' [2453'S, $\left.116^{\circ} 59^{\prime} \mathrm{E}\right]$, L. Glauert, collection date unknown.

\section{Paratypes (17)}

R2609-25, Aurillia Creek, WA.

\section{Current nomenclature}

Uperoleia russelli, see Tyler et al. (1981a).

\section{Remarks}

The collection data for the holotype is not specified in specimen records; however, Glauert visited Landor Station between 8 April and 20 May 1929 for a collecting expedition during which is it likely the specimen was collected (Anonymous 1929a, b, c). Tyler et al. (1981a) stated the collection year for the holotype specimen (R2608) as '(1929?)'. Loveridge (1933) stated 'Twenty-four specimens with the same history as the type' under paratypes; however, he only provided a registration number for one specimen under measurements (MCZ 19424). Parker (1940) lists seven specimens examined, including two from the SUM which are listed as paratypes; however, no registration numbers are presented. Tyler et al. (1981a) presented 
additional information on the holotype specimen and lists of 24 paratypes; however, the origins of the paratype list were not detailed and no specimens from SUM are listed. Tyler et al (1981a) listed 17 paratypes from WAM (R2609-25), six from MCZ (MCZ 1942429) and one from SAMA (SAMA R9723) followed by 'all taken with the holotype'.

\section{Kyarranus kundagungan Ingram \& Corben, 1975}

Ingram, G.J. and Corben, C.J. (1975) A new species of Kyarranus (Anura: Leptodactylidae) from Queensland, Australia. Memoirs of the Queensland Museum 17(2): 335-359 [339].

\section{Paratype}

R45071, Mistake Mountains, 83 km SW Brisbane, Qld.

\section{Current nomenclature}

Philoria kundagungan, see Cogger et al. (1983) and Knowles et al. (2004).

\section{Remarks}

Holotype in the QM collection: QM J23944, 'Mistake Mountains (Lat. $27^{\circ} 53^{\prime} \mathrm{S}$, Long. $152^{\circ} 21^{\prime} \mathrm{E}$ ), about 800 metres above sea level, and $83 \mathrm{~km}$ southwest of Brisbane, SE. Queensland', C.J. Corben and A.K. Smyth, 3 January 1974. Single paratype gifted to WAM by authors, date unknown. Additional paratypes deposited in other collections: seven at QM (QM J23945, J22677-81, J23946), two at AMS (AMS R38193-94; Shea and Sadlier 1999), two at SAMA (SAMA R1392122; Tyler 1976), one at NMV (NMV D33826) and one at QVM (QVM 1974/4/1) (Ingram and Corben 1975).

\section{Pseudophryne brooksi Loveridge, 1933}

Loveridge, A. (1933) Four new crinine frogs from Australia. Occasional Papers of the Boston Society of Natural History 8: 55-60 [59].

\section{Paratype}

R4584*, Manjimup, nr Pemberton, WA [34ำ15'S, $\left.116^{\circ} 09^{\prime} \mathrm{E}\right]$.

\section{Current status}

Junior synonym of Pseudophryne guentheri, see Parker (1940).

\section{Remarks}

Under paratypes, Loveridge (1933) listed registration numbers for five specimens in the MCZ collection (MCZ 13027-31) and stated four others were donated to the AMS, WAM and BMNH, all with the same collection details as the holotype. Of the four paratypes donated, two are held in the BMNH collection (BMNH 1927.8.30.3-4; Parker, 1940), one at AMS (AMS R10911; Shea and Sadlier 1999) and one at WAM. Holotype housed in the MCZ collection: MCZ 13025, from 'Manjimup, near Pemberton, West Australia', collected by W.S. Brooks, 7 February 1927. The WAM paratype has not been sighted in previous type specimen audits dating back to December 1998 or subsequent searches since and is presumed lost.

\section{Pseudophryne douglasi Main, 1964}

Main, A.R. (1964) A new species of Pseudophryne (Anura: Leptodactylidae) from north-western Australia. Western Australian Naturalist 9(3): 66-72 [66].

\section{Holotype}

R21255, 'Kookhabinna Gorge [Barlee Range], WA (23ํํ'S, 11558'E)', A.R. Main, 18 August 1961.

\section{Paratypes (7)}

R11530-34, Shothole Canyon, Northwest Cape [nr Learmonth], WA; R20253, Mount Herbert [nr Tambrey HS], WA; R21256, Kookhabinna Gorge [Barlee Range], WA.

\section{Remarks}

No paratypes were designated in the original description; however, Main referred to 13 specimens under specimens examined (presumably including the holotype), six males, four female and three juveniles from 'Mount Herbert', 'Kookhabinna Gorge, Weeana, Butler's Gorge' and 'Shothole Canyon (N.W. Cape)' and referenced multiple collecting events in the introduction. Under Article 72. (b) and Recommendation 73D of the then current, first edition of the International Code of Zoological Nomenclature (ICZN 1961; Article 72.4.1 and 72.4 .5 of the current fourth edition of the Code (ICZN 1999), the 12 additional specimens (excluding the holotype) are considered paratypes.

At the time of the description, only eight specimens of $P$. douglasi were held in the WAM collection and would have been available to Main. Excluding the holotype, the remaining seven specimens match some of the collection data presented by Main. No specimens associated with the localities Weeana or Butlers Gorge or collected by J.H. Calaby and A. Kluge presented in the description could be located in the WAM collection; however, it is not known if these specimens were deposited at the WAM or were held in the UWA Zoology Department and their current whereabouts are unknown. The five additional paratypes that cannot be located are presumed to be lost. All type specimens are whole specimens stored in $70 \%$ ethanol solution with the exception of $\mathrm{R} 11533$ which is a dry skeleton. 


\section{Pseudophryne nichollsi Harrison, 1927}

Harrison, L. (1927) Notes on some Western Australian frogs, with descriptions of two new species. Records of the Australian Museum 15: 277-287 [284].

\section{Paratypes}

Unknown.

\section{Current nomenclature}

Metacrinia nichollsi, see Roberts and Maxson (1989) and Parker (1940).

\section{Remarks}

Harrison (1927) identified 34 individuals used in the description, 28 collected from 'Pemberton, in Karri country, 218 miles [351 km] south of Perth, 28 August $1926^{\prime}$, WA [342 $\left.26^{\prime} \mathrm{S}, 116^{\circ} 03^{\prime} \mathrm{E}\right]$, and six from 'Deep River,

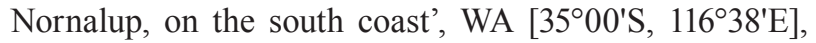
by G.E. Nicholls 30 November 1925. In the description for the species under 'Types' Harrison states 'Holotype female and allotype male in the Macleay Museum of the University of Sydney. Paratype material will be distributed to the Western Australian Museum, Perth, the Australian Museum, Sydney, the British Museum, and the American Museum of Natural History'. There are, however, no specimens in the collection matching the type information provided or any record of specimens being received by the WAM or any other institutions listed by Harrison, including MMUS, see account for Crinia rosea Harrison, 1927 above. The numerous changes to staff and collections at the MMUS throughout its history are likely to have attributed to the unknown whereabouts of type material in the collection, see account for Crinia rosea above.

Parker (1940) made no reference to any specimens matching the type specimen information provided by Harrison in a subsequent publication on Australian frogs. As for Crinia rosea, no specimens or records of any of Harrison's $P$. nichollsi type material being deposited at the MMUS (van der Valk 1984; Glenn Shea, personal communication, 2016), AMS (Shea and Sadlier 1999; Glenn Shea, personal communication, 2016), AMNH (David Dickey, personal communication, 2016), BMNH (Jeff Streicher, personal communication, 2016) or WAM could be located and all type material is presumed lost.

\section{Ranidella bilingua Martin, Tyler \& Davies, 1980}

Martin, A.A., Tyler, M.J. and Davies, M. (1980) A new species of Ranidella (Anura: Leptodactylidae) from northwestern Australia. Copeia 1980(1): 93-99 [94].

\section{Holotype}

R59775, 'from swamp on E side of Spillway Creek at Spillway Bridge, $11.5 \mathrm{~km}$ by road $\mathrm{N}$ of Lake Argyle Tourist Village, Kimberley Division, WA (1601'47"S, $\left.128^{\circ} 47^{\prime} 08^{\prime \prime E}\right)^{\prime}$, M. Davies, A.A. Martin and M.J. Tyler, 20 February 1977.

\section{Paratypes (11)}

R59776-77, Dead Horse Spring, 1.5 km NE Lake Argyle Village, WA; R59778-86, Mitchell Plateau, WA.

\section{Current nomenclature}

Crinia bilingua, see Heyer et al. (1982).

\section{Remarks}

Martin et al. (1980) state 'There are 36 paratypes...'; however, only 35 specimens were listed. There are 11 paratypes held in the WAM collection and the remainder are held in other museum collections: ten at SAMA (SAMA R16833-42), four at KU (KU 177596-97, 177593-94), two at AMS (AMS R74817-18), two at NTM (NTM 5838-39), two at QM (QM J31537-38), two at NMV (NMV D50571-72) and two at BMNH (BMNH 1977.2089, 1977.2090). An original University of Adelaide Zoology tag accompanying the holotype states 'Spillway Swamp, $11.5 \mathrm{~km}$ NE of Lake Argyle, W.A.' as the collection locality. Martin et al. (1980) stated call recordings were collected from the type locality and other nearby localities and provided information on call characteristics including audio spectrograms; however, no information is provided on which calls are associated with which specific male specimen, if any, or the location of recordings. No recordings, analogue or digital, could be located in the WAM collection matching the information provided in the description; however, digital call recordings collected by A.A. Martin with the recording date of 19-20 February 1977 from 'Lake Argyle Village' are housed at NMV following the digitisation of historic analogue recordings belonging to A.A. Martin (Katie Date, personal communication, 2016). While the calls were not linked to specific specimens, based on the date of recording and locality, the recording may belong to a number of specimens including the holotype (R59775) from $11.5 \mathrm{~km} \mathrm{~N}$ Lake Argyle Tourist Village, one of two paratypes (R59776 or R59777) from $1.5 \mathrm{~km}$ NE Lake Argyle Village in the WAM collection or one of eight other paratypes held in BMNH, NTM, QM or SAMA.

\section{Spicospina flammocaerulea Roberts, Horwitz, Wardell-Johnson, Maxson \& Mahony, 1997}

Roberts, J.D., Horwitz, P., Wardell-Johnson, G., Maxson, L.R. and Mahony M.J. (1997) Taxonomy, relationships and conservation of a new genus and species of myobatrachid frog from the high rainfall region of southwestern Australia. Copeia 1997(2): 373-381 [374].

\section{Holotype}

R119457, 'Mountain Road, 30 km NE Walpole, WA' [344ㄴ'S, 116 $57^{\circ} E$ ], P. Horwitz, J.D. Roberts and G. Wardell-Johnson, 24 January 1994. 


\section{Paratypes (4)}

R119458-60, Mountain Road, $30 \mathrm{~km}$ NE Walpole, WA; R126469, Boronia Road, 25 km NE Walpole, WA.

\section{Remarks}

Of the four paratypes in the collection of the WAM, R119460 is an alizarin-alcian stained skeleton specimen with skin stored in a glycol solution and R126469 specimen is a partial dry skeleton with skin stored in a $70 \%$ ethanol solution. The remainder of the type series are whole specimens stored in $70 \%$ ethanol. One additional paratype (R46671) is held in SAMA. Roberts et al. (1997) described the species call structure based on recordings of seven males (cuts 1, 3-8, JDR Cassette no. 69). The sound spectrogram and oscillogram illustrating call structure in the description was from JDR Cassette No. 69.5. All recordings are currently housed in CENRM and are in the process of being digitised. Liver sample of the holotype stored at the EBU.

\section{Taudactylus diurnus Straughan \& Lee, 1966}

Straughan, I.R. and Lee, A.K. (1966) A new genus and species of leptodactylid frog from Queensland. Proceedings of the Royal Society of Queensland 77(6): 63-66 [63].

\section{Paratypes (6)}

R26337-42, Green's Falls, Maiala NP, Mt Glorious, Qld.

\section{Remarks}

Holotype specimen in QM: J13398, 'Green's Falls, Maiala National Park, Mt Glorious, Queensland'

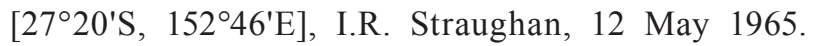
Straughan and Lee (1966) do not list any paratype registration numbers in the description, stating 'Paratypes, including males and females (collected at the same time and place as holotype) are deposited in the Queensland Museum, Australian Museum, Sydney and Western Australian Museum'. Only six specimens (three males, three females) of the $10 \mathrm{~T}$. diurnus specimens held in the WAM collection match the collection data of the holotype presented in the description, R26337-41 we regard as paratypes, with the four other specimens not regarded as paratypes. In addition to the holotype, 13 paratypes are held in the QM (QM J13399-411; Covacevich 1971; Andrew Amey, personal communication, 2016) and a further six paratypes are held in the AM collection (AMS R24656-61; Shea and Sadlier 1999). In the AMS type list (Shea and Sadlier 1999), only three paratype specimens held in the WAM collection were listed; there are in fact six. We note that the species was last seen in 1979 and is presumed extinct (Conrad Hoskin, personal communication, 2016).

\section{Uperoleia aspera Tyler, Davies \& Martin, 1981}

Tyler, M.J., Davies, M. and Martin, A.A. (1981) New and rediscovered species of frogs from the Derby-Broome area of Western Australia. Records of the Western Australian Museum 9(2): 147-172 [159].

\section{Holotype}

R69648, '28 km S of Derby, Kimberley Division, WA $\left(123^{\circ} 43^{\prime} \mathrm{S}, 17^{\circ} 30^{\prime} \mathrm{E}\right.$ [in error, $\left.\left.17^{\circ} 30^{\prime} \mathrm{S}, 123^{\circ} 43^{\prime} \mathrm{E}\right]\right)^{\prime}, \mathrm{M}$. Davies, A.A. Martin and M.J. Tyler, 14 February 1980.

\section{Paratypes (10)}

R69649, $28 \mathrm{~km} \mathrm{~S}$ of Derby, WA; R69650, 20-41 km S Derby, WA; R69651-52, 41 km S Derby, WA; R6965354, Great Northern Hwy, $167 \mathrm{~km}$ E Broome, WA; R69655-58, Great Northern Hwy, 8 km NE Broome, WA.

\section{Remarks}

The latitude and longitude presented for the holotype by Tyler et al. (1981) is in error, the latitude and longitude coordinates have been switched and the correct coordinates associated with the type locality are $17^{\circ} 30^{\prime} \mathrm{S}, 123^{\circ} 43^{\prime} \mathrm{E}$. Of the 19 paratypes designated by Tyler et al. (1981b), 10 are held in the WAM collection, the remainder are held in other collections: six at SAMA (SAMA R18093-97), one at AMS (AMS R95416), one at AMNH (AMNH 106556) and one at $\mathrm{KU}$ (KU 186040). The mating call for the species is described in the species description and supplemented with an audio spectrogram; however, no information is provided to indicate what specimens, if any, the calls are associated with. No recordings, analogue or digital, are held in the WAM collection; however, digitised copies of analogue calls recorded by A.A. Martin are held in the NMV collection, recorded 14 February 1980 from $22 \mathrm{~km}$ south of Derby. The recordings may belong to a number of paratypes held in the WAM collection in addition to specimens held in the BMNH and SAMA collections collected $20-41 \mathrm{~km}$ south of Derby; however, it is not clear which individual specimens the calls belong to based on the limited information associated with the recordings (Katie Date, personal communications, 2016).

\section{Uperoleia borealis Tyler, Martin \& Davies, 1981}

Tyler, M.J., Davies, M. and Martin, A.A. (1981) Australian frogs of the leptodactylid genus Uperoleia Gray. Australian Journal of Zoology Supplementary Series 79: 1-64 [30].

\section{Holotype}

R62474, 'Dead Horse Spring, $3.7 \mathrm{~km}$ north-east of Lake Argyle Tourist Village, Kimberley Division, WA $\left(16^{\circ} 06^{\prime} \mathrm{S}, 128^{\circ} 45^{\prime} \mathrm{E}\right)$ ', M. Davies, A.A. Martin and M.J. Tyler, 19 February 1977. 


\section{Paratypes (7)}

R62475-79, R62480*, Dead Horse Spring, 3.7 km NE Lake Argyle Tourist Village, WA; R62481, Cave Springs, 30 km NE Kununurra, WA.

\section{Remarks}

One paratype specimen, R62480 was not located in February 2008 and has not been located in subsequent searches and type audits; accordingly, the specimen is considered lost. Of the 13 paratypes designated by Tyler et al. (1981a), five are held in SAMA and one in BMNH.

\section{Uperoleia crassa Tyler, Martin \& Davies, 1981}

Tyler, M.J., Davies, M. and Martin, A.A. (1981) Australian frogs of the leptodactylid genus Uperoleia Gray. Australian Journal of Zoology Supplementary Series 79: 1-64 [34].

\section{Holotype}

R59951, 'Amax Campsite, Mitchell Plateau, Kimberley Division, WA (14 $\left.15^{\prime} \mathrm{S}, 125^{\circ} 50^{\prime} \mathrm{E}\right)$ ', M. Davies, A.A. Martin and M.J. Tyler, 28 January 1978.

\section{Paratypes (23)}

R43298-99, R43303-04, R43315-16, R59952-55, R59956-68, Mitchell Plateau, WA.

\section{Remarks}

Tyler et al. (1981a) designated 43 paratypes; however, the description states 'There are 42 paratypes', which is believed to be a typographical error and all 43 specimens are considered paratypes. There are 23 paratypes held in WAM and the remainder are in SAMA (17), KU (2) and BMNH (1). All WAM paratypes have University of Adelaide Zoology specimen tags attached with relevant species, type and collection data. Three additional specimens not listed in the description (R59969-71) also have University of Adelaide Zoology tags attached which state: 'Uperoleia crassa' and 'paratype'; however, there is no mention of these specimens in the description.

\section{Uperoleia glandulosa Davies, Mahony \& Roberts, 1985}

Davies, M., Mahony, M. and Roberts, J.D. (1985) A new species of Uperoleia (Anura: Leptodactylidae) from the Pilbara region, Western Australia. Transactions of the Royal Society of South Australia 109(3): 103-108 [103].

\section{Holotype}

R89489, 'Petermarer Creek, Port Hedland-Broome

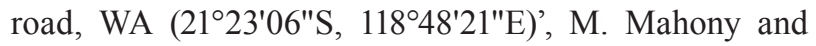
J.D. Roberts, 10 January 1983.

\section{Paratypes (4)}

R22921, 5 km E Mundabullangana HS, WA; R8949092, Petermarer Creek, Port Hedland-Broome Rd, WA.

\section{Remarks}

Of the seven paratypes designated by Davies et al. (1985), four are held in the WAM, two at SAMA (R27081-82) and a single specimen at AMS (AMS $\mathrm{R} 114573)$. Call recordings described in the original description were from two frogs, recordings (JDR Tape 64, tracks 9 and 10), currently held at CENRM; however, it is not known to which individuals of the type series the calls are associated.

\section{Uperoleia lithomoda Tyler, Davies \& Martin, 1981}

Tyler, M.J., Davies, M. and Martin, A.A. (1981) Australian frogs of the leptodactylid genus Uperoleia Gray. Australian Journal of Zoology Supplementary Series 79: 1-64 [43].

\section{Holotype}

R61620, 'Spillway Bridge, $11.5 \mathrm{~km}$ north-east of Lake Argyle Tourist Village, Kimberley Division, WA $\left(16^{\circ} 02^{\prime} \text { S, } 128^{\circ} 47^{\prime} \mathrm{E}\right)^{\prime}$, M. Davies, A.A. Martin and M.J. Tyler, 20 February 1977.

\section{Paratypes (2)}

R61621-22, 11.5 km NE Lake Argyle Tourist Village, WA.

\section{Remarks}

Of the 15 paratypes designated by Tyler et al. (1981a) only two are held by WAM and the remainder are housed in other collections: ten at SAMA (SAMA R17008-12, R17220, R17179-81, R17218), one at NTM (NTM R6936), one at BMNH (BMNH 1978.1207) and one at KU (KU 182219).

\section{Uperoleia micra Doughty \& Roberts, 2008}

Doughty, P. and Roberts, J.D. (2008) A new species of Uperoleia (Anura: Myobatrachidae) from the northwest Kimberley, Western Australia. Zootaxa 1939: $10-18$ [12].

\section{Holotype}

R168043, 'near Bachsten Creek near southwest corner of the Prince Regent River Nature Reserve [now National Park], WA (1559'29"S, 125¹9'54"E)', J.D. Roberts, R. Barrett, P. Doughty and M. Barrett, 22 January 2007.

\section{Paratypes (8)}

R164897-98, Katers Is, WA; R166476, Walcott Inlet, WA; R167989, Prince Regent River NR [NP], WA; R168039-40, R168042, R168044, Bachsten Creek, Prince Regent River NR, WA. 


\section{Remarks}

Of the eight paratypes held in WAM, one is a metamorphosing individual (R166476) and the remainder are adults. Four advertisement calls were recorded and used for the species call description, from R168042 (field recording JDR\#2, track 50), R168043 (field recording JDR\#3, track 3), R168044 (field recording $\mathrm{PD} / \mathrm{MB} \# 1$ ) and a fourth individual that was not captured. Digital call recordings of R168044 and the uncaptured specimen are held at the WAM. Digital recordings of R168042 and R168043 are currently housed at CENRM. Liver sample of the holotype and all eight paratypes stored in $100 \%$ ethanol solution at the WAM.

\section{Uperoleia minima Tyler, Martin \& Davies, 1981}

Tyler, M.J., Davies, M. and Martin, A.A. (1981) Australian frogs of the leptodactylid genus Uperoleia Gray. Australian Journal of Zoology Supplementary Series 79: 1-64 [49].

\section{Holotype}

R62482, 'Amax Crusher Site, $5 \mathrm{~km}$ south-west of the Mining Camp, Mitchell Plateau, Kimberley Division, WA $\left(14^{\circ} 50^{\prime} \mathrm{S}, 125^{\circ} 50^{\prime} \mathrm{E}\right)$ ', M. Davies, A.A. Martin and M.J. Tyler, 14 February 1979.

\section{Paratypes (7)}

R62483-89, Mitchell Plateau, WA.

\section{Remarks}

Of the 15 paratypes, seven are in WAM and the remainder are housed in other collections: six at SAMA (SAMA R17081, R17088-89, R17085-87), one at BMNH (BMNH 1979.4) and one at KU (KU 182200).

\section{Uperoleia saxatilis Catullo, Doughty, Roberts \& Keogh, 2011}

Catullo, R.A., Doughty, P., Roberts, J.D. and Keogh, J.S. (2011) Multi-locus phylogeny and taxonomic revision of Uperoleia toadlets (Anura: Myobatrachidae) from the western arid zone of Australia, with a description of a new species. Zootaxa 2902: 1-43 [23].

\section{Holotype}

R162877, "Turee Creek, WA (2320'37.6"S, $\left.118^{\circ} 01^{\prime} 16.6^{\prime \prime E}\right)^{\prime}$, P. Doughty, C. Stevenson and P.G. Kendrick, May 2006.

\section{Paratypes (10)}

R110883, 36.8 km SSE Pannawonica, WA; R135086, Hamersley Gorge, Karijini NP, WA; R135639, Pinga Creek crossing, WA; R140012, Millstream Chichester
NP, WA; R145561, 80 km S Port Hedland, WA; R154550, Wheelarra Hill, WA; R154764, Brockman Ridge, WA; R156222, Cattle George, WA; R156614, Woodie Woodie Minesite, WA; R166206, 10 km S Nullagine, WA.

\section{Remarks}

Two advertisement calls by the holotype (R162877) were recorded and used in the analysis for the species description; the digital recording is held at the WAM. Liver sample of the holotype stored frozen $\left(-75^{\circ} \mathrm{C}\right)$ at the WAM. Liver sample of all ten paratypes stored frozen $\left(-75^{\circ} \mathrm{C}\right)$ at the WAM.

\section{Uperoleia stridera Catullo, Doughty \& Keogh, 2014}

Catullo, R.A., Doughty, P. and Keogh, J.S. (2014) A new frog species (Myobatrachidae: Uperoleia) from the northern deserts region of Australia, with a redescription of $U$. trachyderma. Zootaxa 3753(3): 251-262 [258].

\section{Holotype}

R164738, '13 km W of Fitzroy Crossing, WA (18 08'25.7"S, $\left.125^{\circ} 29^{\prime} 32.9^{\prime \prime E}\right)^{\prime}$, P. Doughty, P. Oliver and D. Moore, 15 January 2008.

\section{Paratypes (3)}

R164691, 35 km SE Fitzroy Crossing, WA; R164718, R164722, 75 km SE Fitzroy Crossing, WA.

\section{Remarks}

A further six paratypes are in NTM. Advertisement calls by the holotype (R164738; genetic code - Up0261) were recorded and described in the species description, supplemented with an oscillogram and spectrogram. The digital recording of the holotype is held at WAM (field recording PD\#1). Digital recordings of two additional paratypes used in the call description, R164718 (field recording PD.Pond\#2, recording\#1) and R164722 (field recording PD.Pond\#3, recording \#1), are held at WAM. Liver sample of the holotype and all three paratypes stored in $100 \%$ ethanol solution at WAM.

\section{Uperoleia talpa Tyler, Martin \& Davies, 1981}

Tyler, M.J., Davies, M. and Martin, A.A. (1981) Australian frogs of the leptodactylid genus Uperoleia Gray. Australian Journal of Zoology Supplementary Series 79: 1-64 [52].

\section{Holotype}

R62472, '24 km south of Derby, WA $\left(17^{\circ} 37^{\prime} \mathrm{S}\right.$, $\left.123^{\circ} 36^{\prime} \mathrm{E}\right)^{\prime}$, M. Davies, A.A. Martin and M.J. Tyler, 13 February 1979. 


\section{Paratype}

R62473, 24-41 km S Derby, WA.

\section{Remarks}

Two paratypes were designated by Tyler et al. (1981a): one is in WAM and the other in SAMA (SAMA R17174). The holotype (R62472) is a whole specimen in a $70 \%$ ethanol solution and paratype R62473 is an alizarin stained skeleton stored in a glycol solution.

\section{Uperoleia variegata Tyler, Martin \& Davies, 1981}

Tyler, M.J., Davies, M. and Martin, A.A. (1981). Australian frogs of the leptodactylid genus Uperoleia Gray. Australian Journal of Zoology Supplementary Series 79: 1-64 [55].

\section{Holotype}

R62461, 'homestead garden at Gibb River Station, Kimberley Division, WA ( $\left(16^{\circ} 26^{\prime} \mathrm{S}, 126^{\circ} 26^{\prime} \mathrm{E}\right)$ ', A.K. Lee, 10 June 1965.

\section{Paratypes (10) \\ R62462-71, Gibb River Stn, WA.}

\section{Current status}

Junior synonym of Uperoleia lithomoda, see Davies et al. (1986) and Tyler et al. (1987).

\section{Remarks}

Of the 39 paratypes designated by Tyler et al. (1981a), 10 are held in the WAM collection, the remainder are held in other collections: 20 at SAMA (SAMA R17197-215, R17219), seven at KU (KU 181003-09) and two at BMNH (BMNH 1979.5, 1979.6). Davies et al. (1986) state ' $U$. variegata... referred to the synonymy of $U$. lithomoda by Tyler et al. (in press)'; however, the synonymy was first made by Davies et al. (1986) as that publication antedates Tyler et al. (1987).

\section{Family Pelodryadidae}

\section{Cyclorana longipes Tyler \& Martin, 1977}

Tyler, M.J. and Martin, A.A. (1977) Taxonomic studies of some Australian leptodactylid frogs of the genus Cyclorana Steindachner. Records of the South Australian Museum 17(15): 261-276 [271].

\section{Holotype}

R43258, 'Mitchell Plateau, Kimberley Division, WA $\left(140^{\circ} 52^{\prime} \mathrm{S}, 125^{\circ} 50^{\prime} \mathrm{E}\right.$ [in error, $\left.\left.14^{\circ} 52^{\prime} \mathrm{S}, 125^{\circ} 50^{\prime} \mathrm{E}\right]\right)$ ', L.A. Smith and R.E. Johnstone, 5 February 1973.

\section{Paratypes (43)}

R14157, Broome, WA; R32349-51, Wyndham, WA; R42388, Mt Phire, WA; R43199-200, R43268-75, R43294-95, R43346, Mitchell Plateau, WA; R44735-59, Lake Argyle, WA.

\section{Remarks}

The latitude presented for the holotype by Tyler and Martin (1977) added an extra zero; the coordinates provided with the specimen when lodged with the WAM were $14^{\circ} 52^{\prime} \mathrm{S}, 125^{\circ} 50^{\prime} \mathrm{E}$.

\section{Cyclorana maini Tyler \& Martin, 1977}

Tyler, M.J. and Martin, A.A. (1977) Taxonomic studies of some Australian leptodactylid frogs of the genus Cyclorana Steindachner. Records of the South Australian Museum 17: 261-276 [273].

\section{Paratypes (84)}

R1440, Laverton, WA; R1510-11, Booylgoo Stn, WA; R10216, R28634-35, R28638-48, R39193-94, Mundabullangana, WA; R10634, Roebourne, WA; R20546, Nannine, WA; R28486-508, Mt Edgar, WA; R28517, R28536, Jiggalong, WA; R28795, New Yamarna, WA; R28806-07, 44 km SE Leonora, WA; R28984-85, R28987, 8 km S Mundabullangana, WA; R29127-28, Roebourne Christchurch Grammar School, WA; R31444, presumably nr Exmouth, WA; R32373-80, R32382, Koordarrie, WA; R33188, R33212*, R34791, R34793, Woodstock, WA; R3420607, Wittenoom, WA; R34208, S Wanning, WA; R36092, 40 km N Carnarvon, WA; R36094-96, nr Winning, WA; R36105-06, Barrabiddy Creek, WA; R36695, Mandidjarra, WA; R37248, Angel Is, WA; Dampier Archipelago, WA; R39147, Talawana, WA; R40355, Durba Hills, WA; R45665-67, Bamboo Creek, WA.

\section{Remarks}

Tyler and Martin (1977) state 'There are 95 paratypes' but they list 101 registration numbers, all as C. maini. As there is no distinction as to which registration numbers listed, if any, were to be excluded from paratype status, all specimens listed under 'paratypes' are considered paratypes here. Holotype in SAMA: R15191, 'Barrow Creek, NT' $\left[21^{\circ} 25^{\prime} \mathrm{S}\right.$, $\left.133^{\circ} 57^{\prime} \mathrm{E}\right]$, collected by D.F. Gartside and B. Low, 11 December 1971. Six additional paratypes held in the SAMA collection (SAMA 15192, 6311, 14715, R13038 A-D, R1711) and four in the NTM collection (NTM 2309-11 (now NTM R30034-35, 2316 (now NTM R30037), 3177 (now NTM R30079) (Horner 1999). One specimen, R33212, from Woodstock, WA, could not be located and is presumed lost. 


\section{Cyclorana occidentalis Anstis, Price, Roberts, Catalano, Hines, Doughty \& Donnellan, 2016}

Anstis, M., Price, L., Roberts, J.D., Catalano, S.R., Hines, H.B., Doughty, P. and Donnellan, S.C. (2016) Revision of the water-holding frogs, Cyclorana platycephala (Anura: Hylidae), from arid Australia, including a description of a new species. Zootaxa, 4126, 451-479 [469].

\section{Holotype}

R111826, ' $55 \mathrm{~km}$ E Newman, Pilbara, WA (23.4908 $\mathrm{S}$, $\left.120.3172^{\circ} \mathrm{E}\left[23^{\circ} 29^{\prime} 26^{\prime \prime S}, 120^{\circ} 19^{\prime} 01^{\prime \prime E}\right]\right)$, P. Doughty, 4 October 2005.

\section{Paratypes (32)}

R28551, R28553-54, R135042, Jigalong, WA; R28972, 33.6 km S New Mundiwindi, WA; R28977, $22.4 \mathrm{~km} \mathrm{~N}$ Leonora Laverton Road junction, WA; R48990, 12 km E Laverton, WA; R54386, Meekatharra, WA; R61331, 4 km S Mount Narryer HS, WA; R63113, 15 km SSW Nullagine, WA; R63834-35, Condegoon Pool, WA; R64971-72, $11.5 \mathrm{~km}$ N Erlistoun, WA; R103570-71, 20 km N Carnarvon, WA; R113403, 11 km S Pinjin HS, WA; R113405, 40 km N Mavis Rock, WA; R114053, 45 km SW Tangadee HS, WA; R119798, Barrabiddy Creek, WA; R119802-03, 9 km N Carey Downs HS, WA; R129994, R129998, nr Mt Joel, WA; R135899, 74 km WSW Kumarina Roadhouse, WA; R140796-97, between Kumarina Roadhouse and Yanneri Pool, WA; R154928-29, Yalgoo, WA; R165306, 51.3 km S Leinster, WA; R177495-96 [in error, R174495-96], Mount Augustus NP, WA.

\section{Remarks}

No paratypes were designated in the species description; however, the 40 specimens of the species examined listed in the appendix are all considered paratypes under Article 72.4.1 and 72.4.5 of the International Code of Zoological Nomenclature (ICZN 1999). Five additional paratypes held at the AMS (AMS R182001-05) and three at SAMA (SAMA R168162, $\mathrm{R} 168164-65)$. The holotype registration is presented with two different localities; however, both refer to the same location, '55 km E Newman, Pilbara' under the holotype listing and ' $11 \mathrm{~km} \mathrm{~N}$ Red Hill' in the appendix of specimens examined. Two WAM paratype registration numbers are presented in error, R17749596. There are currently no specimens associated with those registration numbers and the correct registrations with specimens matching the locality data presented are R174495-96. Liver sample of the holotype (R111826) stored frozen $\left(-75^{\circ} \mathrm{C}\right)$ at the WAM. Liver samples of 14 paratypes stored frozen $\left(-75^{\circ} \mathrm{C}\right.$; R113403，R113405，R114053，R119798，R119802-03, R129994, R135042, R135899, R140796-97, R15492829, R165306) and two in ethanol (R177495-96) at the
WAM. Heart samples for seven paratypes (R113403, R113405, R114053, R119798, R119802-03, R129994) stored frozen $\left(-75^{\circ} \mathrm{C}\right)$ at the WAM.

\section{Cyclorana vagitus Tyler, Davies \& Martin, 1981}

Tyler, M.J., Davies, M. and Martin, A.A. (1981) New and rediscovered species of frogs from the Derby-Broome area of Western Australia. Records of the Western Australian Museum 9(2): 147-172 [148].

\section{Holotype}

R71037, 'by the roadside at the junction of the Great Northern Highway and the road to Derby, $41 \mathrm{~km} \mathrm{~S}$ of Derby, Kimberley Division, WA (17²4'S, $124^{\circ} 38^{\prime} \mathrm{E}$

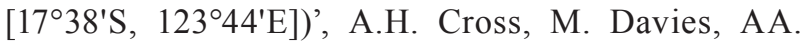
Martin and M.J. Tyler, 14 February 1980.

\section{Paratypes (13)}

R27251, Duncan Hwy, 17 km N Lake Argyle, WA; R58836-37, R71039, Parry Creek Rd, Kununurra, WA; R71029, Camballin, WA; R71030-36, 41 km S Derby, WA; R71038, 29 km S Northern Hwy and Duncan Hwy junction, WA.

\section{Remarks}

Tyler et al. (1981b) state 'There are 26 paratypes...'; however, only 21 specimens were listed. Of the 21 paratypes, 13 are held in the WAM collection and the remainder are held in other museum collections: four at SAMA (SAMA R18008-10, R16535), one at AMS (AMS R95415), one at KU (KU 186039), one at BMNH (1880.4) and one at AMNH (AMNH 106555).

The spelling of the name has been variously reported as 'vagitus' or 'vagita' (for examples see Tyler and Doughty 2009; Tyler and Knight 2011; Anstis 2013). The original etymology indicates vagitus is a noun in apposition or could be so treated, and so does not follow the gender of the generic name, and will always remain 'vagitus' (Meagher 2015).

\section{Hyla coplandi Tyler, 1968}

Tyler, M.J. (1968) A taxonomic study of hylid frogs of the Hyla lesueuri complex occurring in north-western Australia. Records of the South Australian Museum 15: 711-727 [716].

\section{Holotype}

R13722G, 'Inverway Station, NT’ [1751'S, 129³8'E], K.G. Buller, 8 August 1960.

\section{Paratypes (7)}

R13722E*, F*, Inverway Stn, NT; R13724A-D, R13724I, Wave Hill, NT. 


\section{Current nomenclature}

Litoria coplandi, see Tyler (1971).

\section{Remarks}

Two specimens, R13722E and R13722F could not be located and are presumed lost. A single specimen with a damaged registration tag showing only R 13722 was located; however, it is unknown which of the five remaining registrations suffixed with $\mathrm{A}-\mathrm{F}$ this specimen is associated with. A second tag label attached to the specimen with collection and locality information states paratype, though no additional information is available to distinguish which A-F suffix it is associated with. As all specimens registered as R13722 are from the same (type) locality the specimen with the unknown A-F suffix is retained as a paratype. An additional paratype is held in the SAMA collection, SAMA R9103 (formerly WAM R13722D). The three specimens associated with the $\mathrm{R} 13722 \mathrm{~A}-\mathrm{C}$ are listed as specimens of $H$. coplandi examined by Tyler; however, they are not listed as paratypes and so we do not regard them as such.

\section{Hyla latopalmata watjulumensis Copland, 1957}

Copland, S.J. (1957) Presidential address. Australian tree frogs of the genus Hyla. Proceedings of the Linnean Society of New South Wales 82: 9-108 [96].

\section{Syntypes (36)}

R8733-34, 'Thompson's Spring, Argyle Stn, WA' [16 $\left.01^{\circ} \mathrm{S}, 128^{\circ} 56^{\prime} \mathrm{E}\right]$, collected by C.F.H. Jenkins, 23 May 1944; R10491 [in error, 10491*], 10499 (now R138068*), 10501 (now R138069*), 'Napier Broome Bay, WA' [14 $02^{\prime}$ S, $\left.126^{\circ} 36^{\prime} \mathrm{E}\right]$, collected by G.F. Hill, 26 August 1910; R11195-99, R11633-35, R11638, R11896-907, R11932-39, R29763 (formerly part of R11897), R175032 (formerly part of R11896), 'Watjulum [Wotjulum] Mission, WA' [16 $16^{\circ}$ 'S, $\left.123^{\circ} 37^{\prime} \mathrm{E}\right]$, all collected by K.G. Buller and A.M. Douglas, collection date not known (but other specimens in the series were collected in 1954).

\section{Current nomenclature}

Litoria watjulumensis, see Tyler (1968) for species status and Tyler (1971) for generic placement, see Shea and Sadlier (1999) and Tyler and Doughty (2009) for spelling of species epithet.

\section{Remarks}

Copland listed 36 specimens with museum registration numbers and locality data under 'specimens examined and locality records' in the original description; however, no type specimens were designated or presented. In the discussion section of the species description, however, Copland stated 'The type locality Watjulum Mission...'. Tyler (1968) subsequently identified the 29 specimens from the type locality of 'Watjulum Mission' as syntypes and excluded the remaining seven specimens as not from the same locality presented by Copland from WAM (R10491, R1049 and R10501 from Napier Broome Bay and R87333-34 from Thompson's Spring) in addition to specimens from other institutions (AMS R6011 from Napier Broome Bay and MCZ 18000 from Kimberley division). Of the 29 registration numbers presented by Tyler (1968), four syntypes were identified as other species, one as 'Hyla peroni' (=Litoria rothii) (R11195) and three as 'representatives of a new species described in the present paper' (=Hyla [Litoria] coplandi) (R11197, R11638 and R11939). Tyler also identified two specimens bearing the registration number R11897, one of which was subsequently re-registered as R29763. This specimen was then excluded as a syntype despite there being no indication as to whether the specimen was or was not known to Copland at the time of the description. A further seven specimens listed by Copland considered to be syntypes were not located by Tyler (1968): R11196, R11634-35, R11900, R11904-05, R11934. Of the 29 syntypes recognised by Tyler (1968), only 22 syntypes were presented in the WAM Annual Report 1968-1969 (Anonymous 1969) (R11195, R11197-99, R11633，R11638，R11896-99, R11901-03, R11906-07, R11932-33, and R11935-39). Cogger et al. (1983) listed 25 syntype specimens, excluding four of the 29 syntypes presented by Tyler (1968) (R11195, R11197, R11638 and R11939) which were identified as different species (see above). Cogger (1979) and Shea and Sadlier (1999) list the single AMS specimen (R6011) listed by Copland as a syntype, a specimen excluded from the list of syntypes presented by Tyler (1968) for not being from the type locality. Some specimens examined by Copland (1957) were pre-1912 specimens and not formally registered into the current post-1912 registration system with an ' $R$ ' prefix. Of the 36 specimens listed by Copland (1957), three registration numbers pre-date the 1912 herpetological register, 'R.10491, 10499, 10501, W.M.', of which one (R.10491) is erroneously presented with an ' $R$ ' prefix. These pre-1912 registration numbers are listed in the 'Zoological Register 1907' as 'frog' and are part of a series (10491-10502) of frogs collected from Napier Broome Bay, entry dated 'August $29^{\text {th }}$ 1910' (accession date). Two of these specimens, 10499 and 10501 were re-registered as R138068 and R138069 respectively on 8 July 1999. There is no indication which pre-1912 registration number corresponds with the current registration numbers. There is no record to indicate if the third pre-1912 registration number (10491, erroneously presented as R.10491) was ever identified or re-registered.

As Copland (1957) did not designate any type material, all specimens examined are considered syntypes in accordance with Articles 72.1.1, 72.4.1 and Article 73.2 of the International Code for Zoological 
Nomenclature (ICZN 1999). The specimen re-registered by Tyler to R29763 (formerly R11897) is also considered a syntype here and is maintained in the type collection with other syntypes. There are two specimens of $L$. watjulumensis associated with the registration number R11896. To remove duplicate use of the registration R11896 for two specimens, the smaller specimen of the two has been reregistered as R175032. As it is not clear if Copland was aware of the multiple specimens associated with some registrations (R11896 and R11897) and if all specimens were examined, we maintain all four specimens (R11896, R11897, R29763, R175032) as syntypes.

Of the 36 WAM specimens considered to be syntypes, three are specimens of Litoria coplandi (R11197, R11638, R11939), two Litoria meiriana (R8733-34) and one Litoria rothii (R11195). Two specimens, R13806869, for which Copland (1957) originally presented pre1912 registration numbers for (10499 and 10501) could not be located and are considered lost. The third pre1912 registration number presented by Copland (1957) (10491, erroneously presented as R.10491) could not be located and no evidence indicating the specimen was re-registered into the current herpetological catalogue could be located, the specimen's status is unknown and is considered lost.

Tyler (1968) also attempted to emend the specific epithet to wotjulumensis in reference to the type locality Wotjulum Mission, presented as 'Watjulum' in error by Copland; however, the amendment was unjustified as Copland throughout his description used the spelling 'Watjulum'. Hence, there is no evidence within the original description that Copland's use was incorrect and the specific epithet 'watjulumensis' as presented by Copland (1957) is maintained here. As 'Watjulum' Mission is erroneous, we suggest the pronunciation remain as 'wotjulumensis' in reference to the actual name of the mission.

\section{Hyla moorei Copland, 1957}

Copland, S.J. (1957) Presidential Address. Australian tree frogs of the genus Hyla. Proceedings of the Linnean Society of New South Wales 82: 9-108 [83].

\section{Lectotype}

R5981, 'Pemberton, WA' [342ㄱ'S, $\left.116^{\circ} 02^{\prime} \mathrm{E}\right]$, W. Dean, collection date unknown (probably 1930s). Designation by Cogger et al. (1983).

\section{Paralectotypes (38)}

R119, Subiaco, WA; R301*, R302, Denmark, WA; R529-30, East Perth, WA; R627 [in error, R827*], Perth, WA; R1152-53, R2749, Tambellup, WA; R1178, Midland Junction, WA; R1210-13, Lake Yanchep, WA; R2025-
27, R6268-76, Rottnest Is, WA; R3739, Mt Lawley, WA; R3800, Elleker, WA; R4585, Karridale, WA; R4664, Lake Clifton, WA; R5980, R8539-40, R175031 (formerly part of R5981), R176080 (formerly part of R5980), Pemberton, WA; R8404, Bridgetown, WA; R8462, Gin Gin, WA; R9459 (in error, now R176078), no locality data.

\section{Current nomenclature}

Litoria moorei, see Tyler (1971).

\section{Remarks}

A list of specimens examined was provided by Copland (pp. 83-84); however, there is no reference to designation of type specimens and all specimens examined are regarded as syntypes in accordance with Articles 72.1.1, 72.4.1 and Article 73.2 of the International Code for Zoological Nomenclature (ICZN 1999). Copland did not designate any types; however, stated 'Description of R5981 in Western Australian Museum'. The specimen R5981 was incorrectly listed as the holotype in the WAM 1962-1963 Annual Report type list (Anonymous 1963) and subsequently designated as lectotype (through Storr's inference of holotype) by Cogger et al. (1983). There are two specimens associated with the registration number R5981; however, the specimen listed above as the lectotype is consistent with the morphology and meristics of the specimen described by Copland (1957). There is no mention of two specimens by Copland (1957) or Cogger et al. (1983), so it is likely the second specimen was unknown by both sets of authors and possibly not examined. To resolve the status of these specimens, the lectotype specimen retains the original registration number of R5981, while the smaller specimen that was possibly unsighted by previous workers has been reregistered as R175031. There are also two specimens associated with the registration number R5980 of which the smaller of the two has been re-registered as R176080. Due to the uncertainty of which of the specimens with duplicate registrations were examined by Copland or previous workers, both re-registered specimens are also maintained as paralectotypes. The registration number R9459 is associated with two specimens, one L. moorei and one snake identified as Pseudonaja affinis from Guildford, WA. Examination of the original entry in the specimen register reveals the correct specimen associated with this registration number is the $P$. affinis which is also annotated with 'not kept' in the same hand as the accession entry. No additional information relating to the L. moorei specimen could be located; however, it is listed by Copland with 'no data' under specimens examined and locality records. To remove the erroneous duplicate use of the registration, the L. moorei specimen has been reregistered as R176078. One of the parelectotypes (R4585) is a specimen of Litoria adelaidensis. 
Two specimens could not be located: R301 and R627. Of the two specimens, R301 has not been sighted in previous type audits since 1998 or subsequent searches and is presumed lost. The specimen associated with registration number R627 is Ctenotus labillardieri; it is possible that a typographical error occurred in the description and another specimen was intended to be listed. A specimen of L. moorei registered as R827 from East Perth was possibly available to Copland at the time of his description; however, registration data mentions this specimen had six legs, a fact not mentioned by Copland. Registration entries indicate the specimen was disposed of, date unknown. Fiftyeight additional paralectotypes held at AMS: AMS R2347-57; R4953-54; R5297-300; R7476; R7531; R7576-77; R7579-83; R7696; R7698-99; R7703; R7743-45; R10463; R10953; R11537; R131735-39 (formerly 7132, 7144, 7156-57, 7187); R131740-52 (formerly part of R2357); R131753-56 (formerly part of R10953)) (Shea and Sadlier, 1999).

\section{Hyla spaldingi Hosmer, 1964}

Hosmer, W. (1964) A new frog of the genus Hyla from Northern Territory, Australia. American Museum Novitiates 2182: 1-7 [2].

\section{Holotype}

R23886 (formerly AMNH 67835), 'Elizabeth River, 50 miles [80 km, in error] south of Darwin, NT' [12 34 'S, $\left.131^{\circ} 00^{\prime} E\right]$, W. Hosmer, 23 September 1960.

\section{Current status}

Junior synonym of Litoria watjulumensis, fide Tyler (1968).

\section{Remarks}

The holotype was formerly held in the AMNH (Anonymous 1965; Hosmer 1964) and gifted to WAM prior to 1965, and accessioned 27 January 1965. All paratypes remain in the collection of the $\mathrm{AMNH}$ (AMNH 67836-38, 65423-28). The type locality of Elizabeth River does not match the distance from Darwin presented by Hosmer and is likely erroneous, the mouth of Elizabeth River is located approximately 14 $\mathrm{km}$ ESE of Darwin and extends south-east and south for only approximately $28 \mathrm{~km}$.

\section{Litoria aurifera Anstis, Tyler, Roberts, Price \& Doughty, 2010}

Anstis, M., Tyler, M.J., Roberts, J.D., Price, L.C. and Doughty, P. (2010) A new species of Litoria (Anura: Hylidae) with a highly distinctive tadpole from the north-western Kimberley region of Western Australia. Zootaxa 2550: 39-57 [41].

\section{Holotype}

R169913, 'creek near Bachsten Creek, Prince Regent River Nature Reserve [now National Park], WA (1559'18.2"S, 125'19'38.1"E)', J.D. Roberts and P. Doughty, 23 January 2007.

\section{Paratypes (22)}

R168004, R168006, R168008-10, R168013-14, R168016-18, R168059, R168062, R168095, R168114, R168116, R168118, R168129, R168134, R168182-85, Bachsten Creek, Prince Regent River NR [NP], WA.

\section{Remarks}

The holotype was collected as a tadpole and raised to adult by $M$. Anstis before the species description. Paratype specimens include field-collected adults and two adults reared from tadpoles. Two additional paratypes are held in the SAMA collection (SAMA R63001-02). Although not mentioned in the species description, the call description is based on recordings from five male paratype specimens: R168006 (no field recording number), R168013 (field recording JDR\#1, track 33), R168014 (field recording JDR\#2, track 41), R168016 (field recording PD\#1), R168017 (field recording JDR\#5, track 43). Two digital recordings (R168006 and R168016) are held in the WAM, the remaining three paratype calls (R168013, R168014 and R168017) are also digital and currently housed in the CENRM. Liver sample of all 22 paratypes stored in 100\% ethanol solution at the WAM.

\section{Litoria axillaris Doughty, 2011}

Doughty, P. (2011) An emerging frog diversity hotspot in the northwest Kimberley of Western Australia: another new frog species from the high rainfall zone. Records of the Western Australian Museum 26: 209216 [211].

\section{Holotype}

R171472, 'Prince Regent River, Kimberley region, WA (15²'37"S, $\left.125^{\circ} 29^{\prime} 46^{\prime \prime E}\right)^{\prime}$, P. Doughty and M. Pepper, 19 January 2010.

\section{Paratypes (3)}

R169971, 9.3 km ENE King's Cascade, Prince Regent River; R171471, R171473, Prince Regent River, WA.

\section{Remarks}

The species call was described and supplemented in the species description with a spectrogram. Though not mentioned by Doughty (2011) the calls used for the description were from the holotype (R171472) and one paratype (R171473); the oscillogram is of the holotype call. Digital recordings of calls are deposited at the WAM. Liver sample of the holotype stored in $100 \%$ ethanol solution at the WAM. Liver samples of three paratypes stored in $100 \%$ ethanol solution (R171471, $\mathrm{R} 171473)$ and frozen $\left(-75^{\circ} \mathrm{C}\right.$; R169971) at the WAM. 


\section{Litoria cavernicola Tyler \& Davies, 1979}

Tyler, M.J. and Davies, M. (1979) A new species of cavedwelling, hylid frog from Mitchell Plateau, Western Australia. Transactions of the Royal Society of South Australia, 103:149-153 [149].

\section{Holotype}

R43328, '3 km west of Surveyors Pool, Mitchell

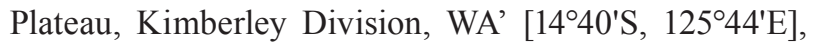
L.A. Smith and R.E. Johnstone, 17 February 1973.

\section{Paratypes (14)}

R43329-30, 3 km W Surveyors Pool, Mitchell Plateau, WA; R60680, R60681*, R60682-84, E Mitchell Falls, WA; R61624-30, Mitchell Plateau, WA.

\section{Remarks}

One paratype (R60681) was not located during a type audit undertaken in 2008 and was not located in subsequent searches and is presumed lost.

\section{Litoria splendida Tyler, Davies \& Martin, 1977}

Tyler, M.J., Davies, M. and Martin, A.A. (1977) A new species of large, green tree frog from northern Western Australia. Transactions of the Royal Society of South Australia 101: 133-138 [133].

\section{Holotype}

R56840, 'Lake Argyle Tourist Village, Kimberley Division, WA' [16 07 'S, $\left.128^{\circ} 44^{\prime} \mathrm{E}\right]$, joint University of Adelaide and University of Melbourne field party [Melu et. al.], 22 February 1977.

\section{Paratypes (6)}

R26818, Old Napier Downs Cave, Napier Downs, WA; R44601-02, Lake Argyle, WA; R47231, Prince Regent River NP, WA; R56779, Kimbolton Spring, Kimbolton Stn, WA; R56780, Drysdale River NP, WA.

\section{Litoria staccato Doughty \& Anstis, 2007}

Doughty, P. and Anstis, M. (2007) A new species of rock-dwelling hylid frog (Anura: Hylidae) from the eastern Kimberley region of Western Australia. Records of the Western Australian Museum 23: 241257 [243].

\section{Holotype}

R162611, 'The Grotto, $30 \mathrm{~km}$ south of Wyndham, WA (1543'31.44"S, $\left.128^{\circ} 16^{\prime} 46.31^{\prime \prime} E\right)^{\prime}$, P. Doughty and C. Mills, 30 January 2006.

\section{Paratypes (11)}

R162512-14, R162537-38, R162612-16, R162620, Parry's Lagoon NR, $30 \mathrm{~km}$ south of Wyndham, WA.

\section{Remarks}

In the description there is a section labelled 'paratypes' (reported here), as well as a section labelled 'Embryos and Tadpoles' (listing 12 such specimens: R162946-57). We do not regard the latter as part of the type series. The calls of the holotype male (R162611) and one paratype (R162612) were recorded and analysed as part of the species description. Digital recordings of calls are held at the WAM. Liver sample of the holotype stored in $100 \%$ ethanol solution at the WAM. Liver sample of all 11 paratypes stored in $100 \%$ ethanol solution at the WAM.

\section{ACKNOWLEDGEMENTS}

The authors would like to thank Marion Anstis for discussions regarding type material of Crinia fimbriata, Andrew Amey (QM) for information on Taudactylus diurnus type material held in the QM, Glenn Shea for a wealth of information on the history of Macleay Museum and its collection and the potential whereabouts of type material for $C$. rosea and $P$. nichollsi, Laurie Smith for discussions regarding historic type specimens held at the WAM and David Dickey (AMNH) and Jeff Streicher (BMNH) for assistance attempting to locate type material potentially held in the AMNH and BMNH collections. The authors are grateful to Glenn Shea and one anonymous reviewer who provided useful comments and suggestions on earlier versions of the manuscript.

\section{REFERENCES}

Anonymous (1896). The Museum. Donations and purchases. West Australian 10.08.1986: 6.

Anonymous (1929a). To collect for Museum Mr. Glauert's tour. Daily News (Perth) 11.04.1929: 11.

Anonymous (1929b). Personal. Daily News (Perth) 20.05.1929: 1.

Aonymous (1929c). Gascoyne fauna Mr. Glauert's tour. Daily News (Perth) 13.06.1929: 6.

Anonymous (1961). Type specimens in the Western Australian Museum (Part 2). Western Australian Museum Annual Report 1960-61: 35-39.

Anonymous (1963). Type specimens in the Western Australian Museum (Part 4). Western Australian Museum Annual Report 1962-63: 38-40.

Anonymous (1964). Type specimens in the Western Australian Museum (Part 5). Western Australian Museum Annual Report 1963-64: 38-40.

Anonymous (1965). Type specimens in the Western Australian Museum (Part 6). Western Australian Museum Annual Report 1964-65: 46-48.

Anonymous (1967). Type specimens of the Western Australian Museum (Part 8). Western Australian Museum Annual Report 1966-67: 59-60.

Anonymous (1969). Type specimens of the Western Australian Museum (Part 10). Western Australian Museum Annual Report 1968-69: 58-60. 
Anonymous (1970). Type specimens in the Western Australian Museum (discontinued in the Annual Report). Western Australian Museum Annual Report 1969-70: 44.

Anstis, M. (2013). Tadpoles and Frogs of Australia. New Holland Publishers, Sydney, NSW. 829 pp.

Anstis, M., Tyler, M.J., Roberts, J.D., Price, L.C. and Doughty, D. (2010). A new species of Litoria (Anura: Hylidae) with a highly distinctive tadpole from the north-western Kimberley region of Western Australia. Zootaxa 2550: $39-57$.

Anstis, M., Price, L., Roberts, J.D., Catalano, S.R., Hines, H.B., Doughty, P. and Donnellan, S.C. (2016). Revision of the water-holding frogs, Cyclorana platycephala (Anura: Hylidae), from arid Australia, including a description of a new species. Zootaxa, 4126, 451-479.

Blake, A.J.D. (1973). Taxonomy and relationships of myobatrachine frogs (Leptodactylidae): A numerical approach. Australian Journal of Zoology 21: 119-149.

Catullo, R.A., Doughty, D., Roberts, J.D. and Keogh, J.S. (2011). Multi-locus phylogeny and taxonomic revision of Uperoleia toadlets (Anura: Myobatrachidae) from the western arid zone of Australia, with a description of a new species. Zootaxa 2902: 1-43.

Catullo, R.A., Doughty, P. and Keogh, J.S. (2014). A new frog species (Myobatrachidae: Uperloeia) from the nothern deserts region of Australia, with a redescription of $U$. trachyderma. Zootaxa 3753: 251-262.

Cogger, H.G. (1979). Type specimens of reptiles and amphibians in the Australian Museum. Records of the Australian Museum 32: 163-210.

Cogger, H.G., Cameron, E.E. and Cogger, H.M. (1983). Zoological Catalogue of Australia. Vol. 1. Amphibia and Reptilia. Australian Government Publishing Service, Canberra, ACT. 313 pp.

Copland, S.J. (1957). Presidential address. Australian tree frogs of the genus Hyla. Proceedings of the Linnean Society of New South Wales 82: 9-108.

Covacevich, J. (1971). Amphibian and reptile type-specimens in the Queensland Museum. Memoirs of the Queensland Museum 16: 401-411.

Davies, M., Mahony, M. and Roberts, J.D. (1985). A new species of Uperoleia (Anura: Leptodactylidae) from the Pilbara region, Western Australia. Transactions of the Royal Society of South Australia 109: 103-108.

Davies, M., McDonald, K.R. and Corben, C. (1986). The genus Uperoleia Gray (Anura: Leptodactylidae) in Queensland, Australia. Proceedings of the Royal Society of Victoria 98: 147-188.

Doughty, P. (2011). An emerging frog diversity hotspot in the northwest Kimberley of Western Australia: another new frog species from the high rainfall zone. Records of the Western Australian Museum 26: 209-216.

Doughty, P. and Anstis, M. (2007). A new species of rockdwelling hylid frog (Anura: Hylidae) from the eastern Kimberley region of Western Australia. Records of the Western Australian Museum 23: 241-257.

Doughty, P., Anstis, M. and Price, L.C. (2009). A new species of Crinia (Anura: Myobatrachidae) from the high rainfall zone of the northwest Kimberley, Western Australia. Records of the Western Australian Museum 25: 127-144.
Doughty, P. and Edwards, D. (2008). A new species of Arenophryne (Anura: Myobatrachidae) from the central coast of Western Australia. Records of the Western Australian Museum 24: 121-131.

Doughty, P. and Roberts, J.D. (2008). A new species of Uperoleia (Anura: Myobatrachidae) from the northwest Kimberley, Western Australia. Zootaxa 1939: 10-18.

Dubois, A. and Frétey, T. (2016). A new nomen for a subfamily of frogs (Amphibia, Anura). Dumerilia 6: 17-23.

Duellman, W.E., Marion, A.B. and Hedges, B. (2016). Phylogenetics, classification, and biogeography of the treefrogs (Amphibia: Anura: Arboranae). Zootaxa 4104: $1-109$.

Ellis, R.J. and Georges, A. (2015). An annotated type catalogue of the turtles (Testudines: Pleurodira: Chelidae) in the collection of the Western Australian Museum. Records of the Western Australian Museum 30: 52-60.

Frost, D.R., Grant, T., Faivovich, J., Bain, R.H., Haas, A., Haddad, C.F.B., de Sá, R.O., Channing, A., Wilkinson, M., Donnellan, S.C., Raxworthy, C.J., Campbell, J.A., Blotto, B.L., Moler, P., Drewes, R.C., Nussbaum, R.A., Lynch, J.D., Green, D.M. and Wheeler, W.C. (2006). The amphibian tree of life. Bulletin of the American Museum of Natural History 297: 1-291.

Goldman, J., Hill, L. and Stanbury, P.J. (1968). Type specimens in the Macleay Museum, University of Sydney. II. amphibians and reptiles. Proceedings of the Linnean Society of New South Wales 93: 427-438.

Harrison, L. (1927). Notes on some Western Australian frogs, with descriptions of two new species. Records of the Australian Museum 15: 277-287.

Heyer, W.R., Daugherty, C.H. and Maxson, L.R. (1982). Systematic resolution of the genera of the Crinia complex (Amphibia: Anura: Myobatrachidae). Proceedings of the Biological Society of Washington 95: 423-427.

Horner, P. (1999). Type specimens of terrestrial vertebrates in the Museum and Art Gallery of the Northern Territory 1973 to 1999. The Bragle, Records of the Museums and Art Galleries of the Northern Territory 15: 55-74.

Horning Jr. D.S. (1993). The amphibians and reptiles in the Macleay Museum University of Sydney. In Herpetology in Australia. A Diverse Discipline. (Eds. D. Lunney and D. Ayers) pp. 227-228. The Royal Zoological Society of New South Wales, Mosman, N.S.W.

Hosmer, W. (1964). A new frog of the genus Hyla from Northern Territory, Australia. American Museum Novitates 2182: 1-7.

Ingram, G.J. and Corben, C.J. (1975). A new species of Kyarranus (Anura: Leptodactylidae) from Queensland, Australia. Memoirs of the Queensland Museum 17: 335-359.

International Commission on Zoological Nomenclature [ICZN]. (1961). International Code of Zoological Nomenclature. First Edition. The International Trust for Zoological Nomenclature, London.

International Commission on Zoological Nomenclature [ICZN]. (1985). International Code of Zoological Nomenclature. Third Edition. The International Trust for Zoological Nomenclature, London. 
International Commission on Zoological Nomenclature [ICZN]. (1999). International Code of Zoological Nomenclature. Fourth Edition. The International Trust for Zoological Nomenclature, London.

International Commission on Zoological Nomenclature [ICZN]. (2003). Declaration 44 - Amendment of Article 74.7.3. Bulletin of Zoological Nomenclature 60: 263.

International Commission on Zoological Nomenclature [ICZN]. (2012). Amendment of Articles 8, 9, 10, 21 and 78 of the International Code of Zoological Nomenclature to expand and refine methods of publication. Zookeys 219 : $1-10$.

Knowles, R., Mahony, M., Armstrong, J. and Donnellan, S. (2004). Systematics of sphagnum frogs of the genus Philoria (Anura: Myobatrachidae) in eastern Australia, with the description of two new species. Records of the Australian Museum 56: 57-74.

Lee, A.K. (1967). Studies in Australian Amphibia II. Taxonomy, ecology, and evolution of the genus Heleioporus Gray (Anura: Leptodactylidae). Australian Journal of Zoology 15: 367-439.

Lee, A.K. and Main, A.R. (1954). Two new species of burrowing frogs of the genus Heelioporus Gray from south-western Australia. Western Australian Naturalist 4: $156-158$.

Littlejohn, M.J. (1957). A new species of frog of the genus Crinia. Western Australian Naturalist 6: 18-23.

Loveridge, A. (1933). Four new crinine frogs from Australia. Occasional Papers of the Boston Society of Natural History 8: 55-60.

Loveridge, A. (1933). A new genus and three new species of crinine frogs from Australia. Occasional Papers of the Boston Society of Natural History 8: 89-94.

Loveridge, A. (1935). Australian amphibia in the Museum of Comparative Zoology Cambridge, Massachusetts. Bulletin of the Museum of Comparative Zoology 78: 1-60.

Mahony, M.J. and Roberts, J.D. (1986). Two new species of desert burrowing frogs of the genus Neobatrachus (Anura: Myobatrachidae) from Western Australia. Records of the Western Australian Museum 13: 155-170.

Main, A.R. (1957a). A new burrowing frog from Western Australia. Western Australian Naturalist 6: 23-24.

Main, A.R. (1957b). Studies in Australian Amphibia I. The genus Crinia Tschudi in south-western Australia and some species from south-eastern Australia. Australian Journal of Zoology 5: 30-55.

Main, A.R. (1963). A new species of Crinia (Anura; Leptodactylidae) from National Park, Nornalup. Western Australian Naturalist 8: 143-144.

Main, A.R. (1964). A new species of Pseudophryne (Anura: Leptodactylidae) from north-western Australia. Western Australian Naturalist 9: 66-72.

Martin, A.A., Tyler, M.J. and Davies, M. (1980). A new species of Ranidella (Anura: Leptodactylidae) from northwestern Australia. Copeia 1980: 93-99.

Meagher, D. (2015). An etymology of the scientific names of Australian amphibians. Herpetofauna 43: 18-60.

Parker, H.W. (1940). The Australian frogs of the family Leptodactylidae. Novitates Zoologicae 42: 1-106.
Roberts, J.D. (2010). Taxonomic status of the Australian burrowing frogs Neobatrachus sudelli, N. centralis and Neoruinosus and clarification of the type specimen of $N$. albipes. Records of the Western Australian Museum 25: 455-458.

Roberts, J.D., Horwitz, P., Wardell-Johnson, G., Maxson, L.R. and Mahony, M.J. (1997). Taxonomy, relationships and conservation of a new genus and species of myobatrachid frog from the high rainfall region of southwestern Australia. Copeia 1997: 373-381.

Roberts, J.D., Mahony, M., Kendrick, P. and Majors, C.M. (1991). A new species of burrowing frog, Neobatrachus (Anura: Myobatrachidae), from the eastern wheatbelt of Western Australia. Records of the Western Australian Museum 15: 23-32.

Roberts, J.D. and Maxson, L.R. (1989). A molecular perspective on relationships of Australian Pseudophryne (Anura: Myobatrachidae). Systematic Zoology 38: 154-165.

Roberts, J.D., Wardell-Johnson, G. and Barendse, W. (1990). Extended descriptions of Geocrinia vitellina and Geocrinia alba (Anura: Myobatrachidae) from south-western Australia, with some comments on the status of $G$. lutea. Records of the Western Australian Museum 14: 427-437.

Sabaj Pérez, M.H. (2014). Standard symbolic codes for institutional resource collections in herpetology and ichthyology: an online reference. Version 5.0 (22 September 2014). American Society of Ichthyologists and Herpetologists, Washington, DC. Available at: http://www. asih.org/sites/default/files/documents/resources/symbolic codes_for_collections_v5.0_sabajperez_2014.pdf [Accessed 20 Oct. 2015].

Schäuble, C.S., Moritz, C. and Slade, R.W. (2000). A molecular phylogeny for the frog genus Limnodynastes (Anura: Myobatrachidae). Molecular Phylogenetics and Evolution 16: 379-391.

Shea, G.M. (2014). From lineages to webs: a history of the Australian Society of Herpetologists. Australian Journal of Zoology 62: 431-447.

Shea, G.M. and Johnston, G.R. (1988). A new species of Notaden (Anura: Leptodactylidae) from the Kimberley Division of Western Australia. Transactions of the Royal Society of South Australia 112: 29-37.

Shea, G.M. and Sadlier, R.A. (1999). A catalogue of the non-fossil amphibian and reptile type specimens in the collection of the Australian Museum: Types currently, previously and purportedly present. Technical Reports of the Australian Museum 15: 1-92.

Smith, L.A. (1981). A revision of the python genera Aspidites and Python (Serpentes: Boidae) in Western Australia. Records of the Western Australian Museum 9: 211-226.

Straughan, I.R. and Lee, A.K. (1966). A new genus and species of leptodactylid frog from Queensland. Proceedings of the Royal Society of Queensland 77: 63-66.

Tyler, M.J. (1968). A taxonomic study of hylid frogs of the Hyla lesueuri complex occuring in north-western Australia. Records of the South Australian Museum 15: 711-727.

Tyler, M.J. (1971). The phylogenetic significance of vocal sac structure in hylid frogs. University of Kansas Publications, Museum of Natural History 19: 319-360. 
Tyler, M.J. (1976). A new genus and two new species of leptodactylid frogs from Western Australia. Records of the Western Australian Museum 4: 45-52.

Tyler, M.J. (1976). Vertebrate type-specimens in the South Australian Museum II. Amphibians. Records of the South Australian Museum 17: 177-180.

Tyler, M.J. and Davies, M. (1979). A new species of cavedwelling, hylid frog from Mitchell Plateau, Western Australia. Transactions of the Royal Society of South Australia 103: 149-153.

Tyler, M.J. and Knight, F. (2011). Field guide to the frogs of Australia, revised version. CSIRO Publishing: Canberra. $188 \mathrm{pp}$.

Tyler, M.J., Davies, M. and Martin, A.A. (1977). A new species of large, green tree frog from northern Western Australia. Transactions of the Royal Society of South Australia 101: 133-138.

Tyler, M.J., Davies, M. and Martin, A.A. (1981a). Australian frogs of the Leptodactylid genus Uperoleia Gray. Australian Journal of Zoology Suplementary Series No. 79: 1-66.

Tyler, M.J., Davies, M. and Martin, A.A. (1981b). New and rediscovered species of frogs from the Derby-Broome area of Western Australia. Records of the Western Australian Museum 9: 147-172.
Tyler, M.J., Davies, M. and Watson, G.F. (1987). Frogs of the Gibb River Road, Kimberley Division, Western Australia. Records of the Western Australian Museum 18: 541-552.

Tyler, M.J., and Doughty, P. (2009). Field guide to frogs of Western Australia. Western Australian Museum, Perth, Western Australia. 158 pp.

Tyler, M.J., and Martin, A.A. (1977). Taxonomic studies of some Australian leptodactylid frogs of the genus Cyclorana Steindachner. Records of the South Australian Museum 17: 261-276.

Tyler, M.J., Martin, A.A. and Davies, M. (1979). Biology and systematics of a new limnodynastine genus (Anura: Leptodactylidae) from north-western Australia. Australian Journal of Zoology 27: 135-150.

van der Valk, A.D. (1984). An annotated catalogue of the amphibian collection (Order: Salientia) of the Macleay Museum, The University of Sydney. Diploma in Museum Studies thesis, University of Sydney, New South Wales. $143 \mathrm{pp}$.

Wardell-Johnson, G. and Roberts, D. (1989). Endangered! Forest frogs. Landscope 5: 17.

MANUSCRIPT RECEIVED 15 FEBRUARY 2016; ACCEPTED 21 MARCH 2017. 